\title{
Painting the Palace of Apries I: ancient binding media and coatings of the reliefs from the Palace of Apries, Lower Egypt
}

\author{
Cecilie Brøns ${ }^{1}$, Kaare Lund Rasmussen ${ }^{2 *}$, Marta Melchiorre Di Crescenzo ${ }^{3}$, Rebecca Stacey ${ }^{3}$ \\ and Anna Lluveras-Tenorio ${ }^{4}$
}

\begin{abstract}
This study gives an account of the organic components (binders and coatings) found in the polychromy of some fragmented architectural reliefs from the Palace of Apries in Memphis, Egypt (26th Dynasty, ca. 589-568 BCE). A column capital and five relief fragments from the collections of the Ny Carlsberg Glyptotek in Copenhagen were chosen for examination, selected because of their well-preserved polychromy. Samples from the fragments were first investigated using Fourier transform infrared (FTIR) spectroscopy to screen for the presence of organic materials and to identify the chemical family to which these materials belong (proteinaceous, polysaccharides or lipid). Only the samples showing the potential presence of organic binder residues were further investigated using gas chromatography with mass spectrometry detection (GC-MS) targeting the analysis towards the detection and identification of compounds belonging to the chemical families identified by FTIR. The detection of polysaccharides in the paint layers on the capital and on two of the fragments indicates the use of plant gums as binding media. The interpretation of the sugar profiles was not straightforward so botanical classification was only possible for one fragment where the results of analysis seem to point to gum arabic. The sample from the same fragment was found to contain animal glue and a second protein material (possibly egg). While the presence of animal glue is probably ascribable to the binder used for the ground layer, the second protein indicates that either the paint layer was bound in a mixture of different binding materials or that the paint layer, bound in a plant gum, was then coated with a proteinaceous material. The surface of two of the investigated samples was partially covered by translucent waxy materials that were identified as a synthetic wax (applied during old conservation treatments) and as beeswax, respectively. It is possible that the beeswax is of ancient origin, selectively applied on yellow areas in order to create a certain glossiness or highlight specific elements.
\end{abstract}

Keywords: Ancient polychromy, Organic binding media, Coatings, GC-MS, Beeswax

\section{Introduction}

Scientific research into ancient polychromy (painted surfaces) has expanded during the past 20 years. However, of the two fundamental constituents of paint, pigments and binders, the former, especially the inorganic pigments, have received by far the greatest attention. This focus can, to a large extent, be explained by the fact that inorganic

\footnotetext{
*Correspondence: klr@sdu.dk

${ }^{2}$ CHART, Institute of Physics, Chemistry and Pharmacy, University of Southern Denmark, Odense, Denmark

Full list of author information is available at the end of the article
}

pigments supply the colour, they are visible and therefore intrinsic to the question of what sculptures looked like in the past, rather than to questions of technique such as how the painting was done. Moreover, traces of ancient polychromy are generally extremely sparse and organic components have usually deteriorated or been lost altogether after centuries-even millennia-in the archaeological record, which makes the study of them an even greater challenge.

The requirement for sampling is a further barrier to research. Much larger sample amounts are needed for analysis of binding media than for pigment identification; 
indeed, inorganic pigments can often be analysed in situ without the need to remove a sample at all. The sparse preservation of polychromy therefore deters the destructive sampling required for binding media analysis and seldom allows for multiple or duplicate samples. In addition, the identification of binders in samples from ancient wall paintings and polychrome art is far from straightforward: not only have the organic binders usually been added in a very low binder-to-pigment ratio, but these works of art are also particularly subject to degradation since they are often located in places where it is difficult to assess standard conservation conditions (open areas, uncontrolled environment, burials, settlements, etc.). Phenomena such as deamidation, hydroxylation, oxidation and carbonylation, partial hydrolysis, extensive intramolecular and intermolecular aggregation, or covalent cross-linking, cause loss of solubility in the organic binder, compromising its analysis. Such phenomena can, moreover, bring about a change in the diagnostic signatures, since the residues of the original organic substances can be replaced by degradation products such as oxalates $[1,2]$.

Binding media, necessary to disperse pigments and ensure their cohesion in the paint layers and adhesion to the support, can consist of different types of organic compounds such as proteinaceous, saccharide and lipid materials, etc. Organic substances were also used as varnishes and coatings to preserve the paint as well as to modify the finish. Knowledge of these organic components is crucial to enhance our understanding of the painting techniques chosen by the artists and of the original appearance of ancient polychrome art and architecture, as the binding medium is not only important in the application of the paint layer but also of great significance as regards the final tone or nuance and gloss of the painting. Furthermore, the identification of organic components is vital to inform the choice of materials and methods for restoration and preservation of the ancient artefacts in museum collections. Finally, besides adding to our knowledge of the original appearance of these artefacts and the techniques employed in their creation, the identification of organic components in polychrome surfaces can also inform us about the raw materials available and their economic context in relation to agriculture, livestock and even trade routes.

In contrast to the generally sparse polychromy preserved on Mediterranean artefacts, the climatic conditions in Egypt favour preservation of ancient polychromy and a wealth of painted artefacts has-and still doescome to light providing a rich corpus of material for research of the materials and techniques of ancient Egyptian painting. Thus, there is still a lot more work to be done concerning the identity of Egyptian polychromy and, in particular, the identification of organic binding media, varnishes and coatings [3]. To date, several analyses of ancient Egyptian binding media have been undertaken [4-13]. The majority of these analyses have been carried out primarily on funerary architecture and funerary artefacts such as cartonnages and mummy shrouds and portraits. A unique opportunity was given by the $\mathrm{Ny}$ Carlsberg Glyptotek (NCG), who allowed the examination and the taking of samples from the fragments of the Palace of Apries from Memphis, Egypt, which have richly preserved polychromy. This provided an exceptional opportunity for acquiring new knowledge of the polychromy of ancient Egyptian palace architecture from an ancient site of great archaeological importance.

This study presents the results of the investigation carried out to shed light on the organic materials used as binding media and finishing layers in this pictorial cycle. The findings are discussed in the light of our current knowledge of materials used in ancient Egyptian polychrome art and architecture.

\section{Ancient Egyptian binding media and coatings: a review}

A range of organic products suitable for use as binding media were available in ancient Egypt. Among these are egg, animal glue, polysaccharide gums, plant resins, fats or oils and beeswax.

\section{Fats and oils}

A range of different fats and oils, including drying oils (such as linseed, walnut and poppy seed oils) were available in ancient Egypt. However, there is, so far, no evidence of the use of animal fats as an adhesive in Pharaonic Egypt and the use of oils has, to date, only been attested in a few instances, such as on the pigmented inlays from Nefermaat's tomb chapel from the 4th Dynasty [14]. Analyses of these inlays showed the presence of fatty acids and diacids that are typical of degraded oils as well as the use of a drying oil, possibly linseed oil [15]. A cartonnage mask from Hawara, dated to the first century $\mathrm{CE}$, showed the presence of two lipids: an unsaturated plant-derived oil and a more saturated animal fat, the latter in the surface layers, while the plant oil was present in the inner layers as well as in the upper surface [16].

\section{Egg}

Egg white, yolk or a mixture of the two can be used as a binding medium. Eggs from wild birds, such as geese or ducks were available in ancient Egypt, while domestic chickens were not common until the Classical period [17]. Yet so far there has been no certain identification of the use of egg as a binder for ancient Egyptian artefacts. The use of egg as a binder is tentatively reported in a study of a mummy portrait dated to the 4th century 
CE [18]. However, as this investigation does not provide a sufficiently stable context for the sampling, we cannot exclude the presence of egg here being related to a restoration material. The use of egg white is also reported in an Egyptian cartonnage from the 1st century CE that was investigated by enzyme-linked immunosorbent assay (ELISA) employing polyclonal antibodies against ovalbu$\min [19]$.

\section{Glue}

Glue is made from collagen, the primary structural protein of animals, which is the principal protein in skin, hides and bones. The sources for glue in ancient Egypt are currently unknown, but would probably have included various mammals and fish that were in use for other purposes (as food or primary sources for leather production). To make these glues, bones, hides, skins, etc. would be cleaned and boiled in water, strained and cooled to a jellied consistency, and finally dried to form a mass, which can be ground to a powder and mixed with warm water to form the adhesive [20]. Several identifications of the use of glue as a binding medium for paint and ground layers for ancient Egyptian polychromy have to date been published. Examples include paint from the Old Kingdom tomb of Nefer at Saqqara [21] and a Roman-Egyptian sarcophagus, where both the white ground as well as the paint layers were identified by pyrolysis to be bound in glue [22]. Examination of the Nebamun paintings, which belonged to a tomb chapel dated to c. $1350 \mathrm{BCE}$, established conclusively the presence of amino acids in two of the paints used, suggesting that proteinaceous binders (probably gelatine) were sometimes used, possibly in association with larger grained pigments and/or varnished areas [13]. A study of an Egyptian cartonnage broad collar from the second half of the 1st millennium BCE provided evidence of the use of glue mixed with oil $[11,23]$. A recent study of three Romano-Egyptian panels dating from 180-200 CE in the J. Paul Getty Museum showed that the panels contained proteinaceous paint media. Animal glue made from the species Bos taurus was detected in the ground layers of all three panels [24]. Examinations of an ancient Egyptian painting on canvas from the 3rd or 4th century CE detected the use of glue as paint medium [25]. The use of a proteinaceous binding medium, probably animal glue, was attested in a recent study of a mummy portrait, dated to the 2nd century CE from the site of Kerke [26].

\section{Gums}

Plant gums are polysaccharide vegetable secretions that can be tapped from incisions in plants. Plant gums used for binding media are produced by a variety of trees and shrubs. Chemically they are high molecular weight polymers made of nine sugars: seven aldose (arabinose, xylose, rhamnose, fucose, mannose, glucose, galactose) and two uronic acids (glucuronic and galacturonic acids). The most widely available gums in ancient Egypt were acacia gum (from Vachellia spp. and Senegalia spp.) and gum tragacanth (from Astragalus spp.), while locust bean gum, tamarind gum and cherry gum have also been suggested [17]. Acacia gum is also known as gum arabic. The high solubility of this specific gum makes it particularly suitable as a painting medium. The use of plant gums as binding media appears to have been widespread in ancient Egypt based on several attestations: paint from stone columns and blocks in the Temple of Karnak from a wide range of periods (18th Dynasty, 19th Dynasty, Ptolemaic and Coptic) were bound with plant gum, possibly an acacia gum [27] and wall paintings from the 19th Dynasty Tomb of Nefertari (QV66) in Thebes were bound with acacia gum $[6,27,28]$. Gums were also used to bind most of the paints for the Nebamun paintings mentioned above. Although in most cases it was not possible to demonstrate the specific sources of the gum, at least one appeared to be from Acacia spp. and some others possibly from Prunus spp. [13]. Furthermore, the red wash of a 18th Dynasty sandstone sarcophagus was found to contain monosaccharides, perhaps from gum tragacanth [27]. Polysaccharide gums were identified as binders in gesso layers in Egyptian cartonnages (c. 21602040 BCE) [29]. A recent study has identified the use of two different plant gums (locust bean gum and gum arabic) as a binder for the polychromy of an ancient Egyptian mummy shroud dated to the period from the 2nd to the 3rd century CE $[27,30]$.

\section{Honey}

Honey and beeswax was readily available in ancient Egypt and would have been available as a paint binder. Among the earliest evidence of beekeeping is a relief in the 5th Dynasty sun temple of Niuserra at Abu Gurob, which depicts beehives and honey harvesting [31]. However, so far there are only few attestations of its use as a binder. A filling material from a 21st Dynasty sarcophagus was bound by an unknown gum mixed with honey and a paint sample from the same artefact was apparently bound with honey alone [27, 32].

\section{Plant resins}

Plant resins consist of complex mixtures of volatile and non-volatile terpenoids or phenolic compounds secreted predominantly by woody plants [33]. Like gums, resins are obtained by tapping from source plants, but, in contrast to gums, they are insoluble in water. They were 
primarily used for varnishing purposes [34]. The use of pistacia resin as a varnish on Egyptian funerary equipment is widely documented $[35,36]$.

\section{Natural waxes}

The most important wax used in ancient art is beeswax, a secretion of the honey bee (Apis mellifica). Beeswax was used as a binding medium as well as a varnish or coating in ancient Egypt. The earliest certain use of beeswax as a binder occurs in the mummy portraits, which primarily originate from the Fayum region. Many of the mummy portraits were executed in the encaustic technique, also known as hot wax painting, which involves using heated beeswax to which pigments are added. The use of beeswax as a binder or a coating has been identified in several examples [37, 38].

No solvent for beeswax appear to have been available in ancient Egypt, which means that wax (if pure) was probably applied melted. That the wax was processed some way before application is indicated by observations of melting points: the melting point of wax samples from mummy portraits does not match that of pure wax [39]. It has therefore been suggested that the medium was beeswax that had been processed possibly by a method described by the ancient author Pliny called 'Punic wax' (Natural History 21.49).

"The Punic wax is prepared in the following manner: yellow wax is first blanched in the open air, after which it is boiled in water from the open sea, with the addition of some nitre. The flower of the wax, or, in other words, the whitest part of it, is then skimmed off with spoons, and poured into a vessel containing a little cold water. After this, it is again boiled in sea-water by itself, which done, the vessel is left to cool. When this operation has been three times repeated, the wax is left in the open air upon a mat of rushes, to dry in the light of the sun and moon; for while the latter adds to its whiteness, the sun helps to dry it. In order, however, that it may not melt, it is the practice to cover it with a linen cloth: if, when it has been thus refined, it is boiled once more, the result is a wax of the greatest possible whiteness.Punic wax is considered the best for all medicinal preparations. Wax is made black by the addition of ashes of papyrus, and a red colour is given to it by the admixture of alkanet; indeed, by the employment of various pigments, it is made to assume various tints, in which state it is used for making models, and for other purposes without number, among which we may mention varnishing walls and armour, to protect them from the air. We have given the other particulars relative to bees and honey, when speaking of the nature of those insects."

The chemical composition and identification of Punic wax in works of art is still subject of debate [40-42]. Pliny's recipe for Punic wax is not entirely clear, as in principle several very different products can be obtained in a similar way, which causes confusion as to its identification. This means that when scholars discuss Punic wax without specifying what components are meant, the subsequent conclusions are not entirely comprehensible [43].

The use of wax for painting is also mentioned by the Roman architect Vitruvius (7.9.3), who uses the term ganosis:

"But anybody who is more particular, and who wants a polished finish of vermilion that will keep its proper colour, should, after the wall has been polished and is dry, apply with a brush Pontic wax melted over a fire and mixed with a little oil; then after this he should bring the wax to a sweat by warming it and the wall at close quarters with charcoal enclosed in an iron vessel; and finally he should smooth it all off by rubbing it down with a wax candle and clean linen cloths, just as naked marble statues are treated." [44]

A recent study of eleven Roman-Egyptian mummy portraits from Tebtunis (Now Umm el-Breigat) in the Fayum region has attested the use of wax as binding medium [26]. Furthermore, an examination carried out by Mackay showed that beeswax had been used as a fixative or a varnish on tombs from the 18th Dynasty at Thebes. There was evidence in some instances that wax had served as a surface coating, applied specifically to coloured areas. In some instances, wax was detected within the paint layer itself, implying its use as a binder. However, the application of the wax with heat could have driven the wax down into the substrate, which means that its presence below the surface was not a positive indication that it served as a binder [45]. Wax has also been identified as having been present in the tomb of Tutankhamun from the 18th Dynasty (c. 1550-1298 BCE), but again it is not clear whether the wax was used as a binder or as a coating [21]. This is also the case for several Egyptian cartonnages on which wax has been attested [29]. A recent examination of an Egyptian coffin from the 26th Dynasty (c. 664-525 $\mathrm{BCE}$ ), showed the use of beeswax as a coating [46] and analyses carried out on the Nebamun paintings in the British Museum also showed the use of beeswax as a varnish, in this case associated with blue/green frit pigments [13]. Finally, a study by Dieteman et al. proved the use of beeswax (as well as animal fat in one of them and egg or glue in another) for four Egyptian mummy portraits [41]. 


\section{The reliefs from the Palace of Apries}

The economic and political centres of ancient Egypt moved during the Third Intermediate and Late Period into the Nile Delta. However, only a few remains of the architectural buildings have been unearthed so far. One of the rare examples of preserved architecture from this period in the Nile Delta is the so-called Palace of Apries, located in the north end of the ruins of Memphis in Lower Egypt. The main palace building was excavated by Petrie during two seasons between 1908 and 1910 . According to Petrie, the palace was part of an extensive complex, which he called a "camp". It is assumed that the "camp" was once a great palace complex, of which the building called the Palace of Apries was only a small part, although possibly the main part. The palace was built on a $13 \mathrm{~m}$ high mudbrick platform, a feature of many monumental buildings from the Late Period in Egypt (as e.g. Deir el-Ballas). The mudbrick walls were lined with limestone slabs on the lower parts and there were limestone pavements, doorways, columns, and stairways. Some of the column capitals recovered from the palace bear the name of King Apries, who was most likely the builder of the complex and the ruler who has given the palace its name. Consequently, the building complex should be dated to the 26th Dynasty to the reign of King Apries, ca. 589-568 BCE, or shortly thereafter.

Fragments of limestone reliefs were recovered during the excavations. Many of them were recovered in a secondary context and without any visible traces of polychromy. They belong to seven large reliefs, originally decorating the Great Gate of the palace. The reliefs depict the 30th anniversary of the pharaoh [47]. One of these seven reliefs was given to the Ny Carlsberg Glyptotek (ÆIN 1046). Furthermore, eleven polychrome relief fragments were acquired by the Ny Carlsberg Glyptotek in 1909 directly from Petrie's excavations. Unfortunately, Petrie gave no details as to where in the palace the fragments were found and their original setting is unknown. It is uncertain if the polychrome reliefs in the Glyptotek belong to a part of the Great Gate (pylon), since the size of the decoration of several of the fragments does not correspond to the remaining decoration of this particular structure-they seem smaller in scale. Yet three of the fragments in the Glyptotek are indeed larger in scale (ÆIN 1048, 1050, and 1060). These three fragments might originally have belonged to wall scenes in the palace depicting the king under a star-filled blue sky (ÆIN 1052 and 1054) [48]. The style and motifs of the remaining fragments also correspond to the decoration of the Great Gate (pylon), which may indicate that they were part of its decoration; but of scenes, which it has been impossible to reconstruct [49]. The fragments must have been in a dry, protected location, since their original polychromy is very well preserved.

A column capital (ÆIN 1045) and five relief fragments (ÆIN 1048, ÆIN 1049, ÆIN 1057, ÆIN 1059, and ÆIN 1060) were chosen for examination based on their wellpreserved polychromy.

\section{Artefacts and sampling \\ Atin 1045 [50]}

ÆIN 1045 constitutes a complete monolith column capital of white limestone in the shape of a rosette of palm leaves, tied around the upper end of the column shaft. The capital is covered in paint in different green nuances, which seems to have been applied twice in two separate layers. Furthermore, the use of gold leaf is observed on the capital, on the palm leaves and the base. On the palm leaves, the gold is primarily preserved in the recesses. The green paint was sampled from one of the leaves, close to the midrib (Fig. 1).

H. $85 \mathrm{~cm}$. D. $75 / 44 \mathrm{~cm}$.

\section{Ain 1048 [51]}

The relief fragment bears the remains of a monumental inscription. From right to left are hieroglyphs representing a wooden column, an animal skin with a tail, a feather,

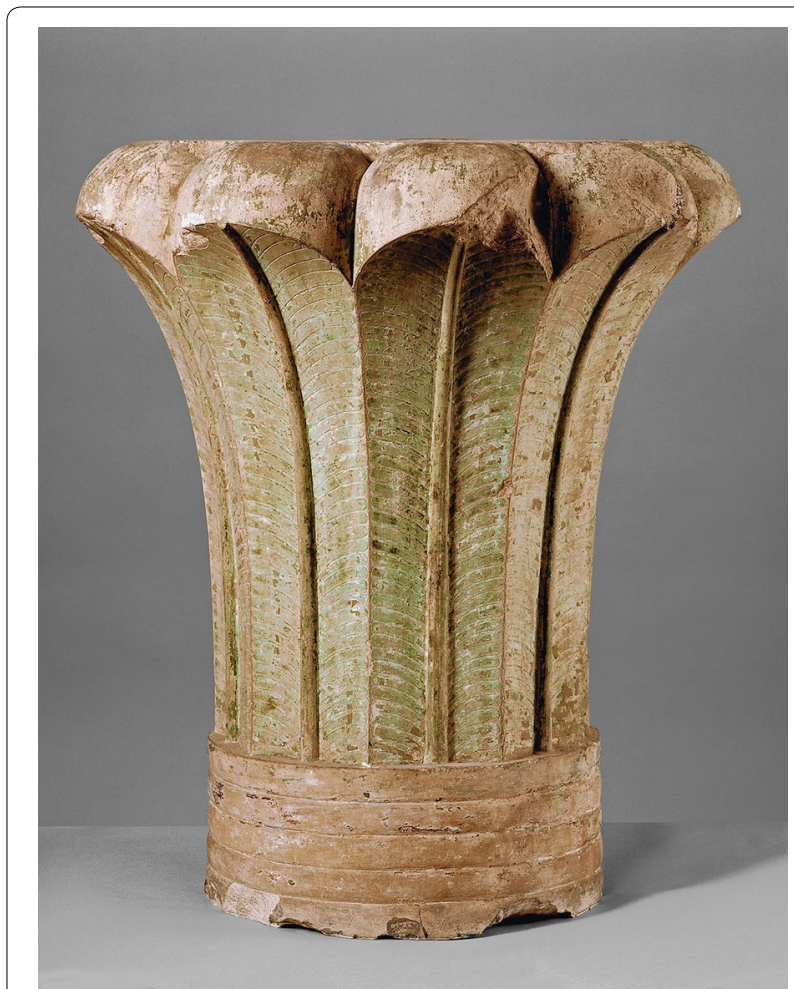

Fig. 1 Column capital from the Palace of Apries. Ny Carlsberg Glyptotek, inv. no. ÆIN 1045 
three vases in a stand, and half a loaf of bread. Together the hieroglyphs form part of the epithets of the sun god Behdeti. Underneath the hieroglyphs is a falcon, which has no relation to the inscription. The paint is applied on a thin layer of plaster. The column is brown, the animal skin has a wide band of green dots, the feather is green, the vases and the half loaf are blue.

One sample was taken from the half loaf of bread (Fig. 2a).

H. $39 \mathrm{~cm}$. W. $28 \mathrm{~cm}$. D. $6 \mathrm{~cm}$.

\section{A Ein 1057 [52]}

The relief fragment is decorated with a large bird's wing, carved in low relief and painted in shades of green. One sample was taken from one of the feathers close to the bottom of the fragments (Fig. 2b).

H. $15 \mathrm{~cm}$. W. $18 \mathrm{~cm}$. D. $3.8 \mathrm{~cm}$.

\section{A Ein 1059 [53]}

The relief fragment bears the remains of an inscription: two fragmented hieroglyphs, originally representing a pair of cow horns and a road with bushes along its sides. These
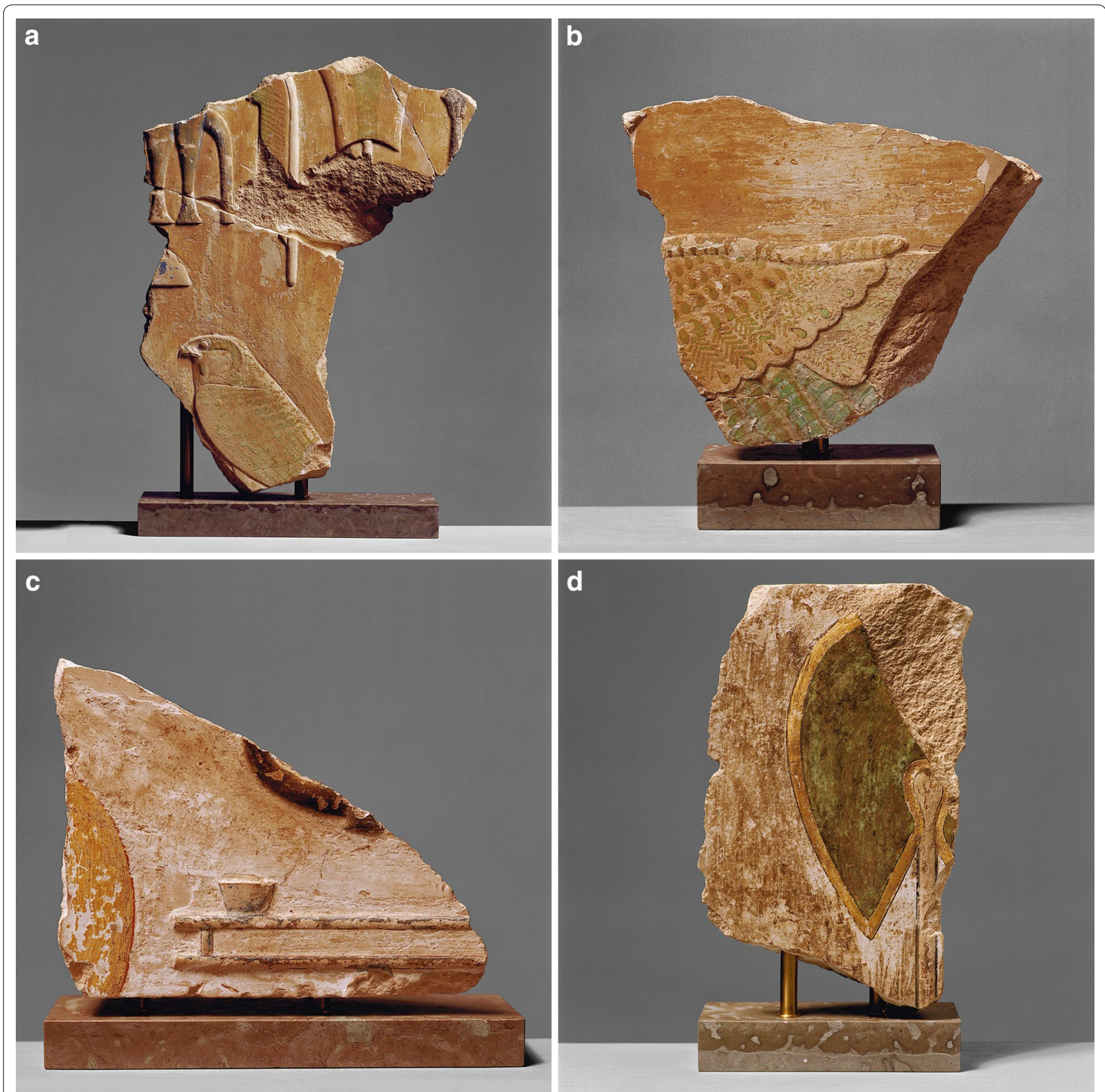

Fig. 2 Relief fragments from the Palace of Apries. Ny Carlsberg Glyptotek, inv. nos. ÆEIN 1048 (a), 1057 (b), 1059 (c), 1060 (d) 
hieroglyphs are the beginning of the name of the jackal god Wepwawet. To the left of the inscription, part of a feather of a Wepwawet standard is visible. There are rich traces of colour on the fragment: the horns are brown, the road bluish, and the feather yellow with red outlining. One sample was taken from the yellow paint of the feather (Fig. 2c).

H $10.4 \mathrm{~cm}$. W. $14 \mathrm{~cm}$. D. $4 \mathrm{~cm}$.

\section{AEin 1060 [54]}

The fragment carries decoration in the form of a lotus leaf with a long vertical shaft. The decoration is carved in relief and is painted green, yellow, and brown. A corresponding motif is depicted behind the king on the large limestone relief from the Great Gate in the NCG (inv. no. ÆIN 1046), although the NCG example is smaller. Surface examination of the fragment by digital microscopy as well as UV-induced fluorescence photography showed residues of an organic coating on top of the paint layer. One sample was taken from the yellow paint of the central part of the lotus (Fig. 2d).

H. $24.3 \mathrm{~cm}$. W. $14.6 \mathrm{~cm}$. D. $8.2 \mathrm{~cm}$.

\section{Methodology and analytical apparatus}

Sampling and analyses were carried out in two different phases.

The column capital (ÆIN 1045) and reliefs ÆIN 1048, ÆIN 1057 and ÆIN 1059 were investigated in collaboration with the Department of Scientific Research of the British Museum in 2014, within the framework of the project Transmission and Transformation. Ancient polychromy in its architectural context [55].

The samples were first investigated using Fourier transform infrared (FTIR) spectroscopy to screen for the presence of organic materials and to identify the chemical family to which these materials belong (proteinaceous, polysaccharides or lipid). Only the samples showing the potential presence of organic binder residues were further investigated using gas-chromatography mass spectrometry (GC-MS) targeting the analysis towards the detection and identification of the compounds belonging to the chemical families identified by FTIR.

Relief ÆIN 1060 was investigated in 2016, in collaboration with the University of Pisa by means of a multistep analytical procedure that characterises all organic compounds from the same microsample, avoiding interference from inorganic components [56].

A more detailed description of the analytical methods used is given below.

\section{Fourier transform infrared (FTIR) spectroscopy-British Museum}

The samples were examined under an optical microscope [57] and micro-flakes were removed from the different layers to be analysed using Fourier transform infrared (FTIR) spectroscopy.

The analyses were performed on the flattened flakes using a Nicolet 6700 spectrometer with Continuum IR microscope (Cassegrain $15 \times$ objective and MCT/A detector). Interferograms were collected over 64 scans, at a resolution of $4 \mathrm{~cm}^{-1}$, in the spectral range 4000$650 \mathrm{~cm}^{-1}$. The spectral data, collected in transmission through a diamond micro-compression cell or in reflection on aluminium-coated slides, were processed using OMNIC 8.3 software and expressed as absorbance.

\section{Gas chromatography-mass spectrometry (GC-MS)- British Museum}

The sampling strategy for the organic analysis using GCMS was largely dictated by the material available and the thickness of the paint/coating layers. The paint layers were separated from the limestone support and the rendering layers to which they are applied, but it was not possible to individually separate the paint/coating layers themselves as they were too thin to allow viable samples to be taken. Thus, the samples investigated using GC-MS comprised the full structure of the paint layers at the spot they were taken, including potential residues of organic coatings. Each sample was around $100 \mu \mathrm{g}$ in weight and was separated into two fractions, the analysis of the first fraction was targeted towards the detection and identification of monosaccharides, which could, for instance, be found in plant gums and honey. The second fraction was used for amino acids analysis to check for proteinaceous components. The samples were prepared as follows:

1. For the monosaccharides the samples were first hydrolysed with $0.5 \mathrm{M}$ methanolic hydrochloric acid $(\mathrm{HCl})$, heated overnight at $80{ }^{\circ} \mathrm{C}$ and dried under a stream of nitrogen. Prior to analysis they were derivatised with Sigma-Sil-A (1:3:9 ratio of trimethylchlorosilane (TMCS), hexamethyldisilazane (HMDS) and pyridine), heated at $80^{\circ} \mathrm{C}$ for $1 \mathrm{~h}$, re-evaporated under nitrogen and reconstituted with hexane. This method is based on the procedure described by Bleton et al. [58].

2. For the analysis of amino acids/lipids the samples were first added with norleucine (internal standard), hydrolysed with $6 \mathrm{M} \mathrm{HCl}$, heated overnight at $105^{\circ} \mathrm{C}$ and dried under nitrogen at $60{ }^{\circ} \mathrm{C}$. The samples were dried again after agitation with high purity water and denatured ethanol (1:1 ratio). Prior to analysis the samples were derivatised with a silylation reagent (3:7 ratio of $N$-(tert-butyldimethylsilyl)- $N$-methyltrifluoroacetamide (MTBSTFA)/tert-butyldimethylsilyl chloride (TBDMCS) and pyridine hydrochloride solution), warmed at $60{ }^{\circ} \mathrm{C}$ for $30 \mathrm{~min}$ and then 
heated at $105{ }^{\circ} \mathrm{C}$ for $5 \mathrm{~h}$. This method is based on Schilling [59] and Simek et al. [60].

The samples were analysed using an Agilent 6890N GC coupled to an Agilent 5973N MSD. An Agilent AS7683 autosampler was used for the introduction of $1 \mu \mathrm{L}$ samples.

1. The monosaccharide samples were injected in the splitless mode at $250{ }^{\circ} \mathrm{C}$ and $10 \mathrm{psi}$, and with a purge time of $0.8 \mathrm{~min}$. The carrier gas was He with a constant flow of $1.5 \mathrm{~mL} \mathrm{~min}{ }^{-1}$. The column used was an Agilent HP5-MS, $30 \mathrm{~m} \times 0.25 \mathrm{~mm}, 0.25 \mu \mathrm{m}$ film thickness with $1 \mathrm{~m} \times 0.53 \mathrm{~mm}$ retention gap. The furnace temperatures were run from 40 to $130{ }^{\circ} \mathrm{C}$ at $9{ }^{\circ} \mathrm{C} \mathrm{min}-1$, then to $290{ }^{\circ} \mathrm{C}$ at $2{ }^{\circ} \mathrm{C} \mathrm{min}^{-1}$ with the final temperature maintained for $10 \mathrm{~min}$. In the MS zone the temperatures were $280{ }^{\circ} \mathrm{C}$ at the interface and $230{ }^{\circ} \mathrm{C}$ at the source. The acquisition was conducted in scan mode $\left(29-650 \mathrm{amu} \mathrm{s}^{-1}\right)$; the solvent delay was $5 \mathrm{~min}$.

2. The amino acid/lipid samples were injected in the splitless mode at $300{ }^{\circ} \mathrm{C}$ and 10 psi pressure; the purge time was $0.8 \mathrm{~min}$. The carrier gas was He with a constant flow of $1.5 \mathrm{~mL} \mathrm{~min}^{-1}$. The column used was an Agilent HP5-MS, $30 \mathrm{~m} \times 0.25 \mathrm{~mm}, 0.25 \mu \mathrm{m}$ film thickness with $1 \mathrm{~m} \times 0.53 \mathrm{~mm}$ retention gap. The oven temperature was maintained for $1 \mathrm{~min}$ isothermal hold at $80{ }^{\circ} \mathrm{C}$, then run to $300{ }^{\circ} \mathrm{C}$ at $20^{\circ} \mathrm{C}$ $\mathrm{min}^{-1}$, where the final temperature was maintained for $3 \mathrm{~min}$. In the MS zone the temperatures were $300{ }^{\circ} \mathrm{C}$ at the interface and $230{ }^{\circ} \mathrm{C}$ at the source. The acquisition was conducted in scan mode (29-650 $\mathrm{amu} \mathrm{s}^{-1}$ ); the solvent delay was $5 \mathrm{~min}$.

Mass spectral data were interpreted manually with the aid of the NIST/EPA/NIH Mass Spectral Library version 2.0 and by comparison with published data $[13,58]$.

\section{Gas chromatography-mass spectrometry (GC-MS)—Pisa University}

The GC-MS procedure employed allows identification of polysaccharide, proteinaceous, glycerolipid materials, as well as waxes and terpenoid resins in the same micro-sample [61]. The procedure is based on a multistep chemical pre-treatment of the sample, in order to obtain three different fractions to be analysed separately by GC-MS: an amino acid, a saccharide and a lipid-resinous fraction. The detailed operating conditions and analytical procedure are described in detail elsewhere [56].

Analyses were carried out using a $6890 \mathrm{~N}$ GC System Gas Chromatograph (Agilent Technologies, Palo Alto,
CA, USA), coupled with a 5975 Mass Selective Detector (Agilent Technologies, Palo Alto, CA, USA) with a single quadrupole mass spectrometer, equipped with a PTV injector. The mass spectrometer was operating in the electron impact (EI) positive mode $(70 \mathrm{eV})$. The MS transfer line temperature was $280^{\circ} \mathrm{C}$, the MS ion source temperature was kept at $230{ }^{\circ} \mathrm{C}$ and the MS quadruple temperature was at $150{ }^{\circ} \mathrm{C}$. A microwave MLS-1200 MEGA (Milestone Microwave Laboratory System) technologic MDR, High Performance Microwave Digestion with Exhaust Module EM-45/A is used for the hydrolysis and the saponification of the GC-MS fractions.

The quantitative determination of amino acids, aldoses and uronic acids, aliphatic mono- and dicarboxylic acids is performed by using standard solutions, building calibration curves, and evaluating daily recoveries. Running blanks of the procedure highlighted a low level of contamination. The detection limit (LOD) and the quantitation limit (LOQ) of amino acids, aldoses, uronic acids, and fatty and dicarboxylic acids were calculated. At a statistical significance level of 0.05 , the LODs and LOQs obtained of the proteinaceous, glycerolipids and saccharide materials were as follows:

\section{Proteinaceous material: $\quad$ LOD $0.19 \mu \mathrm{g}$; LOQ $0.30 \mu \mathrm{g}$; Glycerolipids: LOD $0.35 \mu \mathrm{g}$; LOQ $0.50 \mu \mathrm{g}$; Saccharide material: $\quad$ LOD $0.01 \mu \mathrm{g}$; LOQ $0.02 \mu \mathrm{g}$.}

Proteinaceous materials were identified based on the percentage composition of 11 determined amino acids. Using these data as variables, multivariate statistical analysis, namely principal component analysis (PCA), was applied (XLSTAT 6.0, Addoinsoft, France) on the correlation matrix of the data and the first two components account for $96.3 \%$ of the data. In the resulting score plots samples were represented together with the data set of 121 reference samples of animal glue, egg, and casein [62]. The presence and absence of the sugars was used for the identification of the saccharide content by means of a decisional scheme already published in the literature [63].

\section{Results}

\section{Capital ÆIN 1045}

The micro-fragment taken from the capital separated into two parts during sampling: ÆIN 1045_1 and ÆIN 1045_2. As indicated by optical microscopic examinations, both samples include the limestone support, which is covered with a beige layer (interpreted as a ground applied to prepare the stone surface before painting) and then the green paint layer. The surface of sample ÆIN $1045 \_1$ is partially covered by a grey layer, whilst a translucent layer is seen to partially cover the surface of sample ÆIN 1045_2 (Fig. 3). 
The main absorption features in the FTIR spectrum of the green paint layer (Fig. 4) are ascribable to calcium oxalate, a compound that is likely to originate from alteration processes of the original paint media $\left(\mathrm{Ca}\left(\mathrm{C}_{2} \mathrm{O}_{4}\right) \cdot 2 \mathrm{H}_{2} \mathrm{O}: 3337,1621,1318,782 \mathrm{~cm}^{-1}\right)$. Other absorption features indicate the presence of slight amounts of calcium carbonate $\left(\mathrm{CaCO}_{3}: 1439,874 \mathrm{~cm}^{-1}\right)$ and gypsum $\left(\mathrm{CaSO}_{4} \cdot 2 \mathrm{H}_{2} \mathrm{O}: 3406,1102,672 \mathrm{~cm}^{-1}\right)$ mixed with a green pigment that was possibly identified as atacamite $\left(\mathrm{Cu}_{2} \mathrm{Cl}(\mathrm{OH})_{3}: 918\right.$ and $\left.840 \mathrm{~cm}^{-1}\right)$.

Due to the high inorganic to organic ratio and the alteration processes of the organic materials (as suggested by the detection of calcium oxalate) it was not possible to identify spectral bands clearly ascribable to a paint binder. Some of the spectral features assigned to the inorganic components overlap with the absorption bands of polysaccharide materials (broad absorption between 3500 and $3000 \mathrm{~cm}^{-1}$, absorptions around 1620 and $1100 \mathrm{~cm}^{-1}$ ) and the absorption around $1558 \mathrm{~cm}^{-1}$ might be interpreted as the amide II band of a protein material [64].

The spectrum from the grey layer on the surface of sample ÆIN 1045_1 indicated the presence of silicate compounds (that are possibly constituents of surface dirt and dust) and calcium oxalate.

The spectrum from the translucent layer on the surface of sample ÆIN 1045_2 showed absorption features ascribable to a wax (absorptions at 2918, 2850 and $1468 \mathrm{~cm}^{-1}$ ) that is thought to be of synthetic origin due to the absence of the carbonyl stretching at
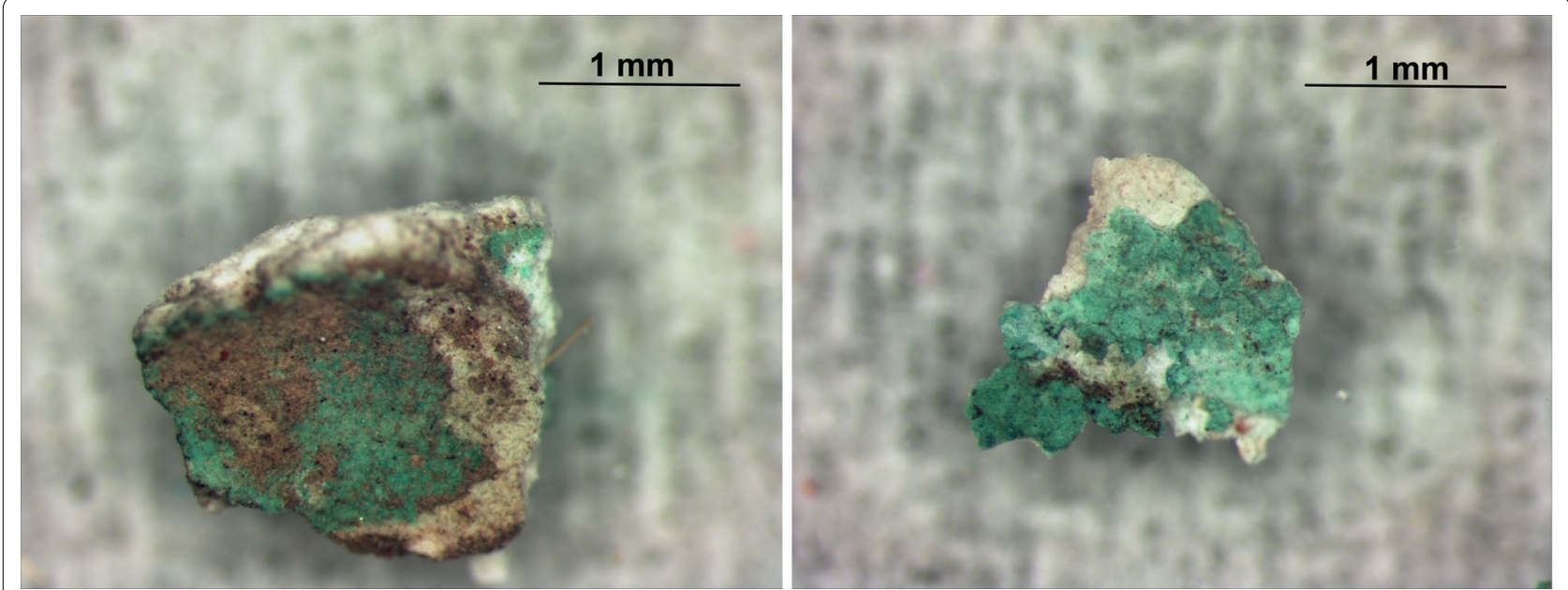

Fig. 3 Microphotographs of sample ÆEIN 1045_1 (on the left) and sample ÆIN 1045_2 (on the right)

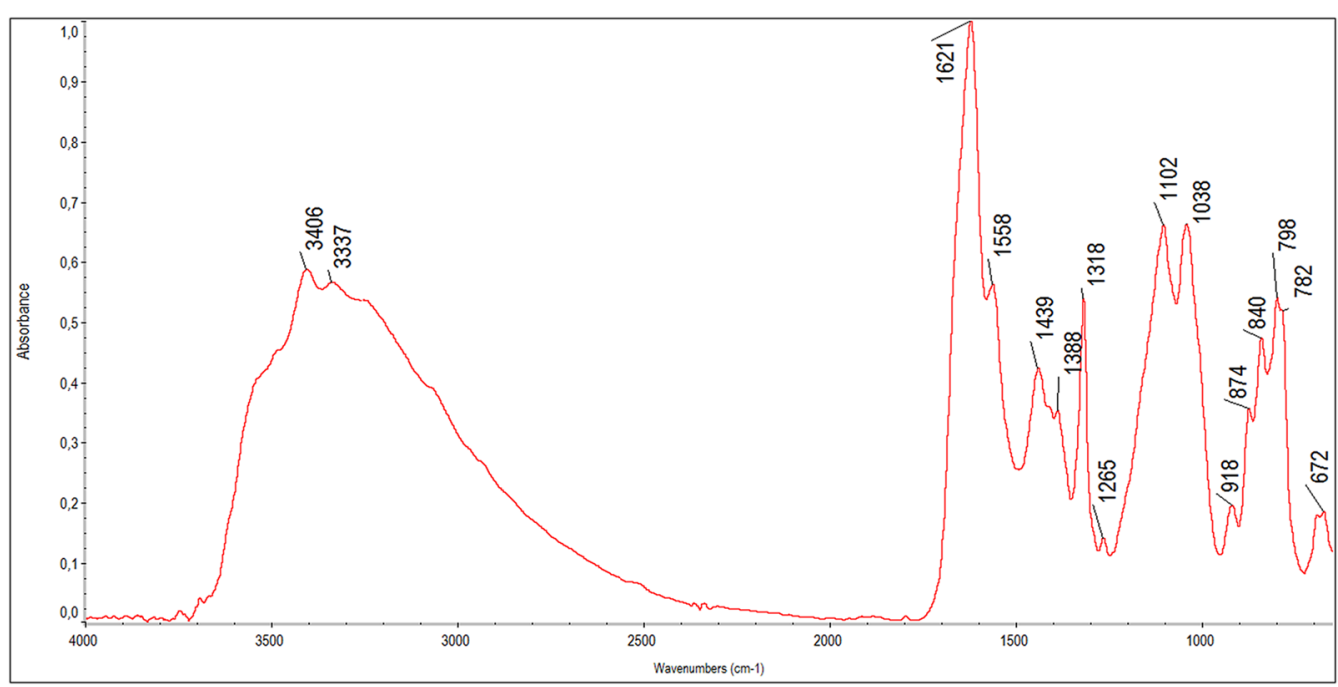

Fig. 4 FTIR spectrum from the green paint layer of capital ÆEIN 1045 
about $1740 \mathrm{~cm}^{-1}$, that is seen in natural waxes (such as beeswax) containing esters of higher fatty acids with fatty alcohols band seen for beeswax (Fig. 5). The other absorption bands seen in the spectrum are ascribable to inorganic components from the underlying paint layer: the pigment atacamite (absorptions at 3448 and $3354 \mathrm{~cm}^{-1}$ ), calcium oxalate (absorptions at 1622, 1319 and $778 \mathrm{~cm}^{-1}$ ) and calcium carbonate (absorptions at 1420 and $875 \mathrm{~cm}^{-1}$ ).

On the basis of the FTIR results, the paint layers were further investigated by means of gas chromatographymass spectrometry (GC-MS). The sub-sample scraped from $Æ I N ~ 1045 \_1$ consisted of the green paint layer and some of the uppermost grey layer. The sub-sample scraped from ÆIN 1045_2 consisted of the green paint layer and some of the uppermost translucent layer. Both sub-samples were separated into two fractions that were investigated targeting the analysis towards the detection and identification of carbohydrates and amino acids/ lipids respectively.

The results and interpretation of qualitative analysis of sugars and uronic acids indicated the presence of arabinose, galactose and xylose (Fig. 6). While these components are characteristics of plant gum media, it was not possible to identify a specific gum source as no minor sugar components and uronic acids were detected. In neither sample were proteinaceous materials detected. The chromatograms of sample ÆIN 1045_2 did not show features that can be ascribed to beeswax.

\section{Æin 1048}

The sample shows a largely ground blue pigment applied on top of a white layer, interpretable as a ground (Fig. 7). The results of FTIR analysis did not provide information useful for the identification of the paint binder. As the paint layer is very thin and firmly adhered to the ground, it was not possible to separate a sample to be investigated by GC-MS.

\section{Atin 1057}

Optical microscopic examination indicates that the limestone support is covered by a white layer, followed by greenish-blue and light yellow paint layers (Fig. 8). The results of FTIR analysis indicate the presence of calcium oxalate in each paint layer as well as in the white wash, suggesting the presence of original organic materials that had altered with time. Due to the very small size of the sample and the very large amount of calcium oxalate identified by FTIR, it was decided not to investigate the sample using $\mathrm{GC}-\mathrm{MS}$.

\section{Æin 1059}

Optical microscopy examination indicates that the yellow paint was applied on a white layer that can be interpreted as a ground (Fig. 9). Also in this case the use of FTIR spectroscopy for screening the presence of organic materials did not allow the identification of spectral features that can be clearly assigned to a paint binder. The main absorption features from the yellow paint layer (Fig. 10) are ascribable to calcium carbonate, gypsum and calcium oxalate. Some of these features overlap with the absorption bands characteristic of polysaccharide binders (broad absorption band between 3500 and $3000 \mathrm{~cm}^{-1}$, absorptions around 1620 and $1100 \mathrm{~cm}^{-1}$ ) and the absorption around $1555 \mathrm{~cm}^{-1}$ may indicate the presence of residues of a protein material. On the basis of the FTIR results, the yellow paint layer was further investigated using GC-MS, targeting the analysis towards the

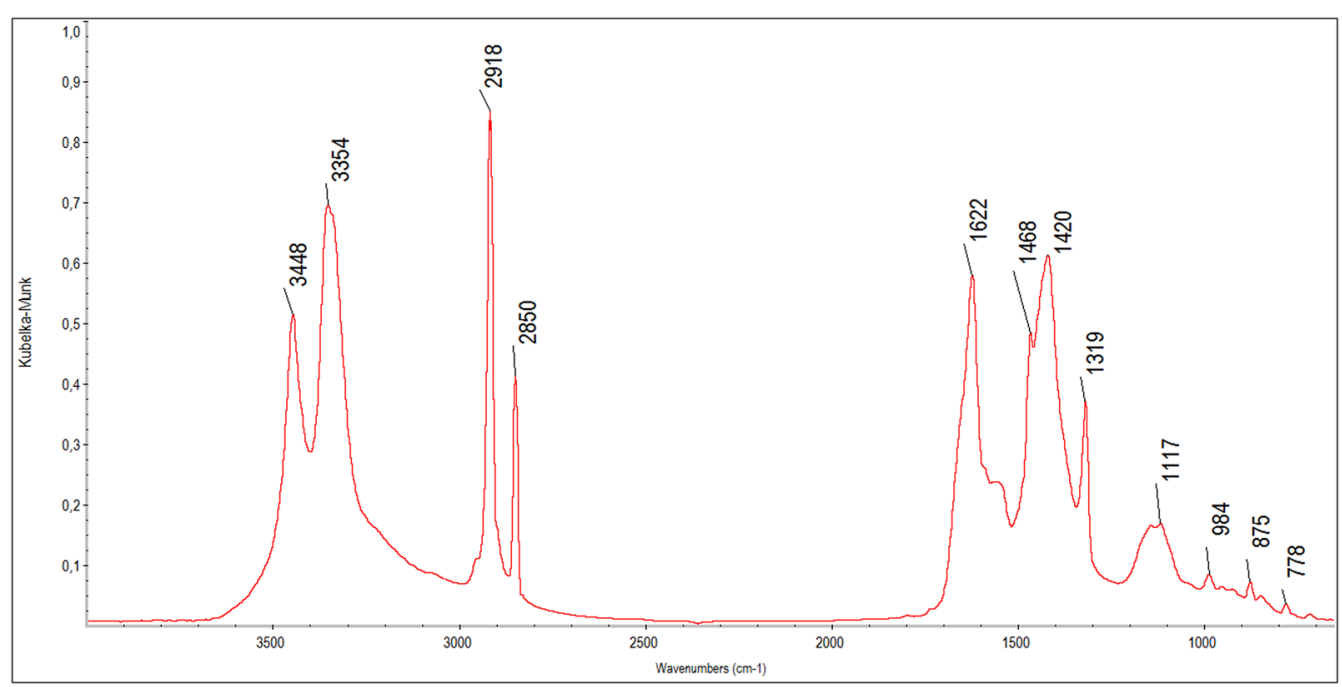

Fig. 5 FTIR spectrum from the translucent surface layer of sample ÆIN 1045_2 


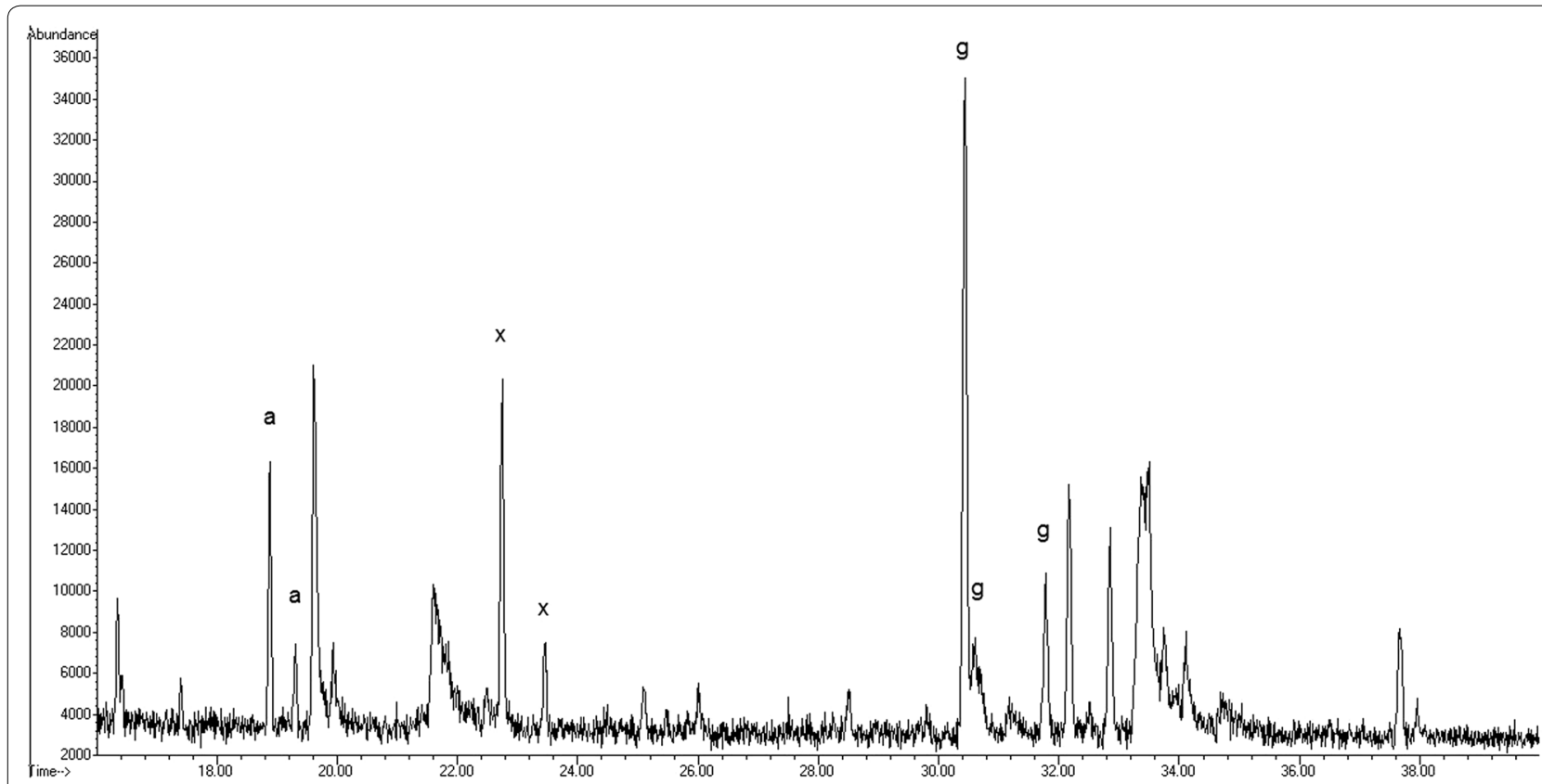

Fig. 6 Partial (16-40 min) total ion chromatogram of sample AIN 1045_1. Sugars detected are identified as follows: $a=$ arabinose; $x=x y l o s e ;$ $\mathrm{g}=$ galactose

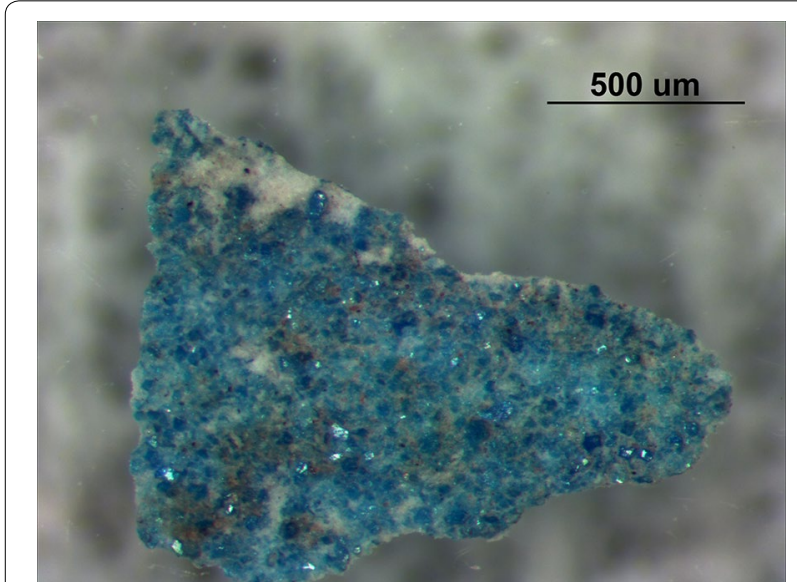

Fig. 7 Microphotograph of sample ÆIN 1048

detection and identification of carbohydrates and amino acids.

The results and interpretation of qualitative analysis of sugars and uronic acids indicated the presence of arabinose, rhamnose, galactose and xylose (Fig. 11). While these components are characteristics of plant gum media it was not possible to identify a specific gum source as no minor sugar components and uronic acids were detected. Proteinaceous materials were not detected.

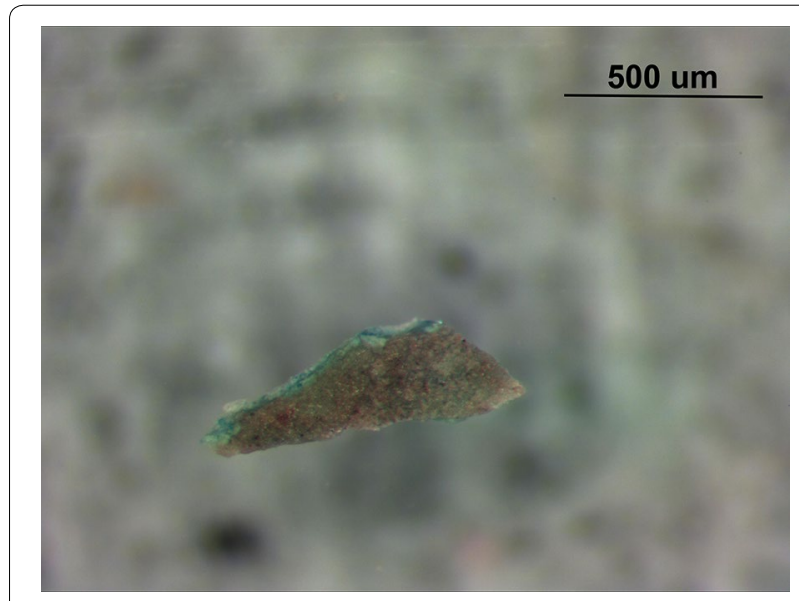

Fig. 8 Microphotograph of sample AIN 1057

\section{A Ain 1060}

The sample shows a thin layer of yellow paint applied on a white layer, interpretable as a ground. The surface of the paint layer is covered by a whitish material (Fig. 12). Two different sub-samples were obtained for analysis by scraping the sample with a scalpel. The first sub-sample consisted of the whitish material on the surface of the painting (1060_W), the second sub-sample mainly consisted of the yellow paint layer (1060_PL). As the paint layer was very thin and firmly adhered to the ground it is 


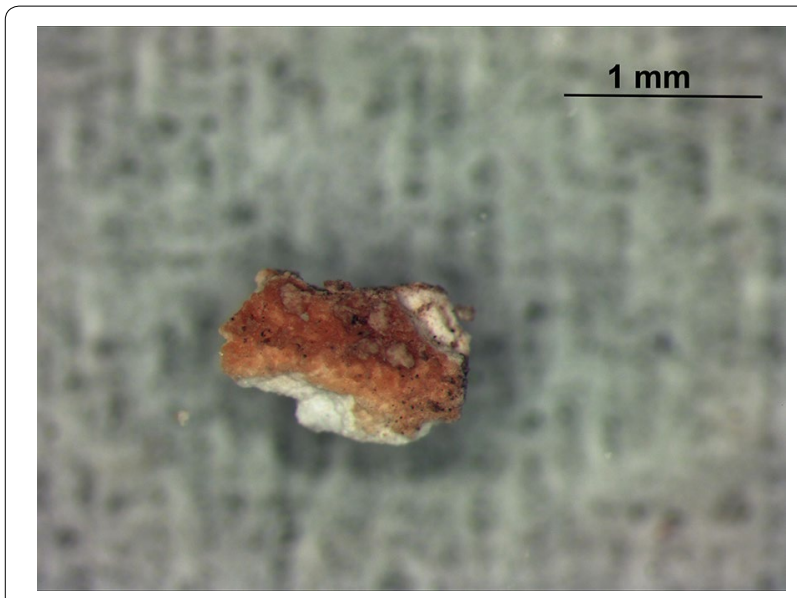

Fig. 9 Microphotograph of sample AEIN 1059

possible that the sub-sample 1060_PL contained some of the ground itself.

In Sample 1060_W no proteinaceous or saccharide materials were detected above the detection limit of the procedure (see above). The main features in the chromatograms of the lipid-resinous fraction (Fig. 13) are the linear alkanes (from C27 to C37), long-chain fatty acids (from $\mathrm{C} 14$ to $\mathrm{C} 28$ of which the most abundant is palmitic acid), long-chain linear alcohols (from C18 to C32), $\omega-1$ hydroxyacids, $\omega-2$ hydroxyacids of which the most abundant are 14 and 15 hydroxypalmitic acids, respectively, and $\alpha-(\omega-1)$ diols (1,23-tetracosandiol, 1,25-hexacosandiol, 1,27-octacosandiol). The presence of all these compounds and the profile of the chromatogram are consistent with the presence of beeswax [65].
The analytical procedure used was able to detect the presence of a saccharide material in sample $1060 \mathrm{PL}$ (Fig. 14).

The saccharide profile obtained showed the presence of a large amount of glucose together with a lower amount of arabinose and galactose (Fig. 14a). These sugars are fairly stable and present in the majority of cases even when ageing in the presence of pigments occurs, which means that they can be used for identification, using the decisional schemes published [63]. The absence of fucose, which is usually present in tragacanth gum, and mannose, which is present in fruit tree gum, seems to point to an identification of gum arabic.

Gum arabic was already identified for samples collected from the wall paintings of the Nefertari Tomb in Luxor, Egypt [6]. A second saccharide material such as starch could have been added to the mixture consistent with the high amount of glucose present [63].

The amino acid content of sample 1060_PL was found to be above the quantitation limit of the procedure used (as defined in "Methodology and analytical apparatus" section), allowing us to establish the presence of a proteinaceous material in the sample. The presence of hydroxyproline, marker of collagen, allowed the identification of animal glue in the sample. The amino acid profile and the score plot of the sample are reported in Table 1 and Fig. 15, respectively. The PCA score plot shows that sample 1060_PL is not well located in any of the clusters, pointing to the use of a complex mixture of proteinaceous materials in this case. The lipid resinous fraction of the sample however, showed the presence of cholesterol that is related to egg. A mixture of both materials or a differentiate

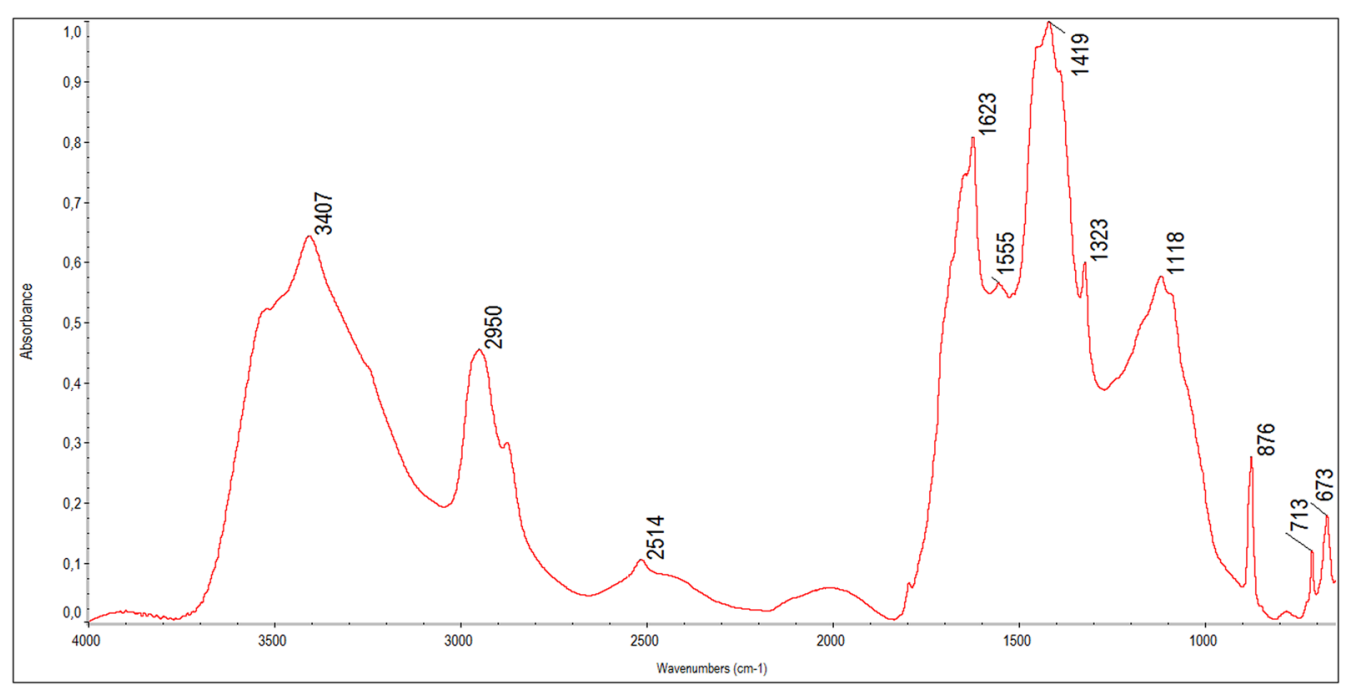

Fig. 10 FTIR spectrum from the yellow layer of sample ÆIN 1059 

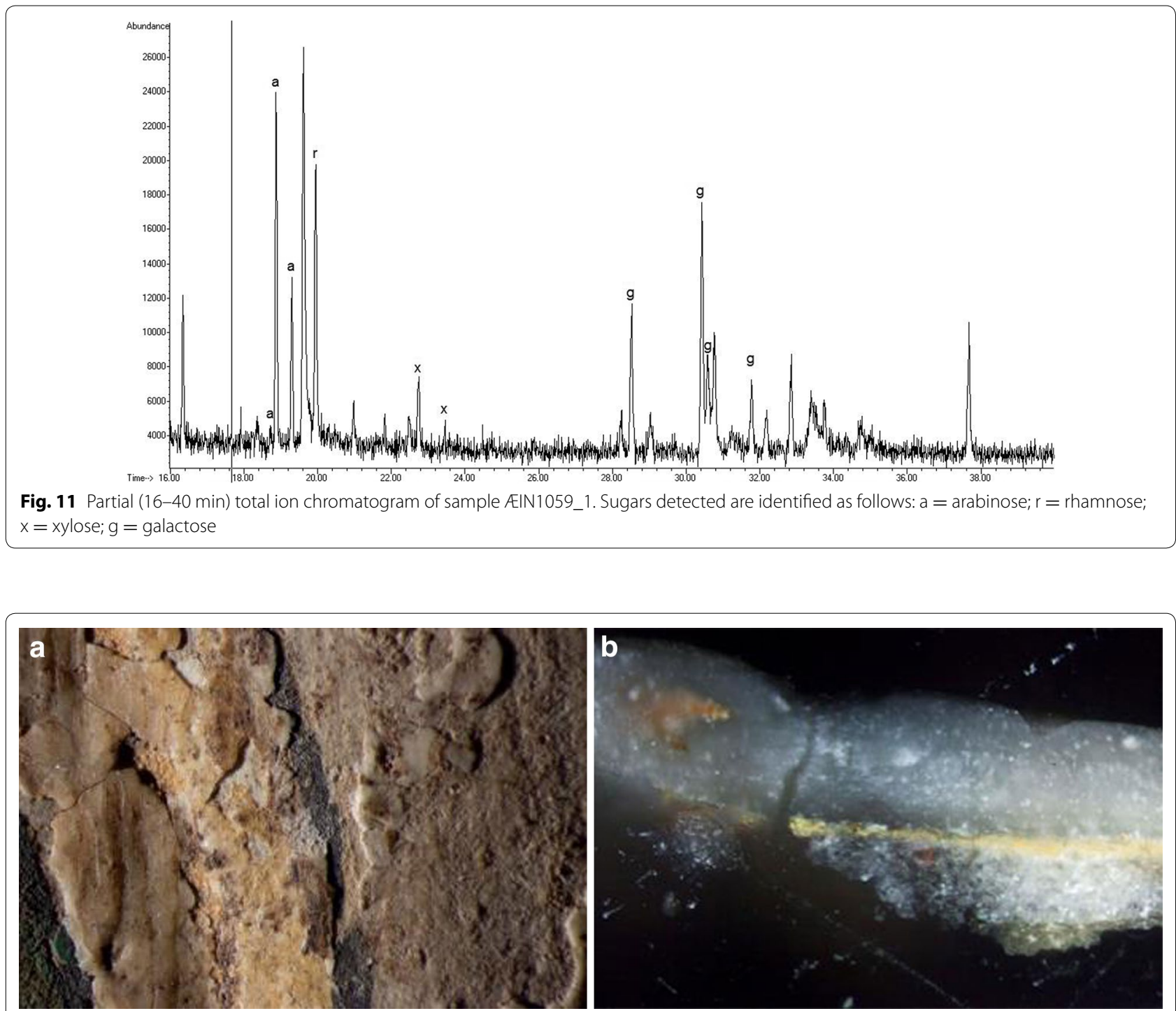

Fig. 12 a Area of the painting fragment from where the sample ÆIN 1060 was taken. b Optical microscope image of a cross-section of the sample EIN 1060 showing three different layers, from bottom up: the white ground, the yellow paint layer, and a thick superficial whitish layer

use of them for the yellow paint layer and the preparation can be hypothesised.

The chromatogram of the lipid resinous fraction showed also some of the characteristic compounds related to beeswax though the abundance of these compounds was clearly lower than in sub-sample 1060_W pointing to contamination, both from the mechanical sampling or by penetration of the superficial wax during the application.

\section{Discussion}

The results of the investigation are summarised in Table 2.

\section{Paint binders}

Sugars characteristic of plant gum media were identified in the paint layers from capital ÆIN 1045 and relief ÆIN 1059. Qualitative analysis of sugars and uronic acids by the method used to investigate these samples can, to some extent, distinguish between different plant gums on the basis of occurrence and/or relative abundance of individual sugar components. In this case, probably due to the small sample sizes, only the most abundant sugars were detected and it was not possible to identify a specific gum.

A plant gum was also identified in the paint layer of relief $Æ I N ~ 1060$. Considering the databases of saccharide 


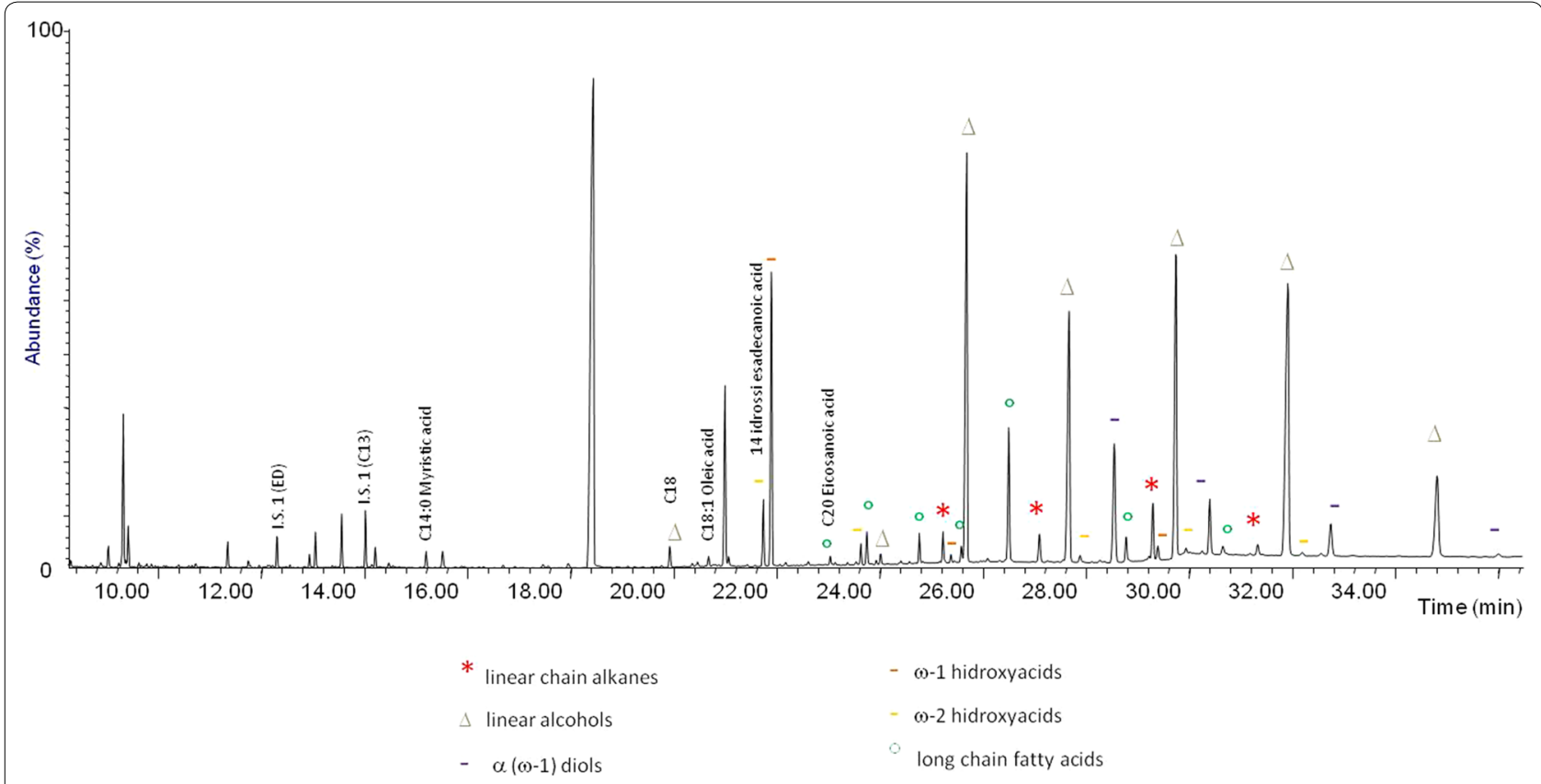

Fig. 13 TIC Chromatogram of the lipid-resinous fraction of the sample 1060_W

containing materials in the literature [6], results could be consistent with the presence of acacia gum. The paint layer of relief ÆIN 1060 was also found to contain a substantial proportion of glucose, not typically a constituent of gums. Whilst glucose has been reported from gum tragacanth, the absence of fucose in the sugars profile of this sample does not support the presence of this gum.

In paints, glucose is usually attributed to the presence of a sucrose source, such as honey or syrup, which was added to reduce brittleness in the gum [66]. A sucrose source does not seem to be present in this case as the chromatograms did not show peaks related to ketoses (including fructose). The high quantity of glucose might then be ascribed to the presence of a second saccharide material such as starch [63].

In the sample from relief ÆIN 1060, a mixture of proteinaceous materials was also detected together with the plant gum. Though identification is not straightforward, a mixture of animal glue with a second proteinaceous binder (possibly whole egg) is suggested by the data. It should be borne in mind that it is not certain whether the sample investigated by means of GC-MS contained only the paint layer or comprised some of the white ground beneath, and it is therefore possible that the identified organic materials were originally used to bind different layers, with the animal glue used for the preparatory layer and a mixture of the other protein compound and gum arabic used in the paint layer.
The combined presence of plant gums and protein materials was also found in the wall paintings from the Nefertari tomb in Luxor, which were painted by using gum arabic as binder and an egg-white glaze [6, 67]. Moreover, a combination of plant oils and animal glue was used for the cartonnage mask from Hawara, dated to the first century $\mathrm{CE}$, which showed the presence of two lipids: an unsaturated plant-derived oil and a more saturated animal fat, the latter in the surface layers, while the plant oil was present in the inner layers as well as in the upper surface [16].

As far as relief ÆIN 1060 is concerned, it seems unlikely that the second proteinaceous compound was used as a glaze as no evidence of proteins was found in the scraping from the uppermost surface of the painting (sub-sample ÆIN 1060, see discussion below).

The hypothesis of the use of animal glue in the preparatory layers and gum arabic in mixture with a small amount of another protein material to bind the paint layer is supported by the results of an investigation carried out on two Egyptian cartonnages, dated to the first century CE, in the Petrie Museum Collection [19]. Both cartonnages have a fine ground layer of pure calcite. ELISA (Enzyme Linked ImmunoSorbent Assay) analysis of the fine calcite layer from one of the cartonnages indicated the presence of animal glue, while the analysis of the paint layer gave a weak response for animal glue, a weak response for plant gum (possibly acacia gum) and a 


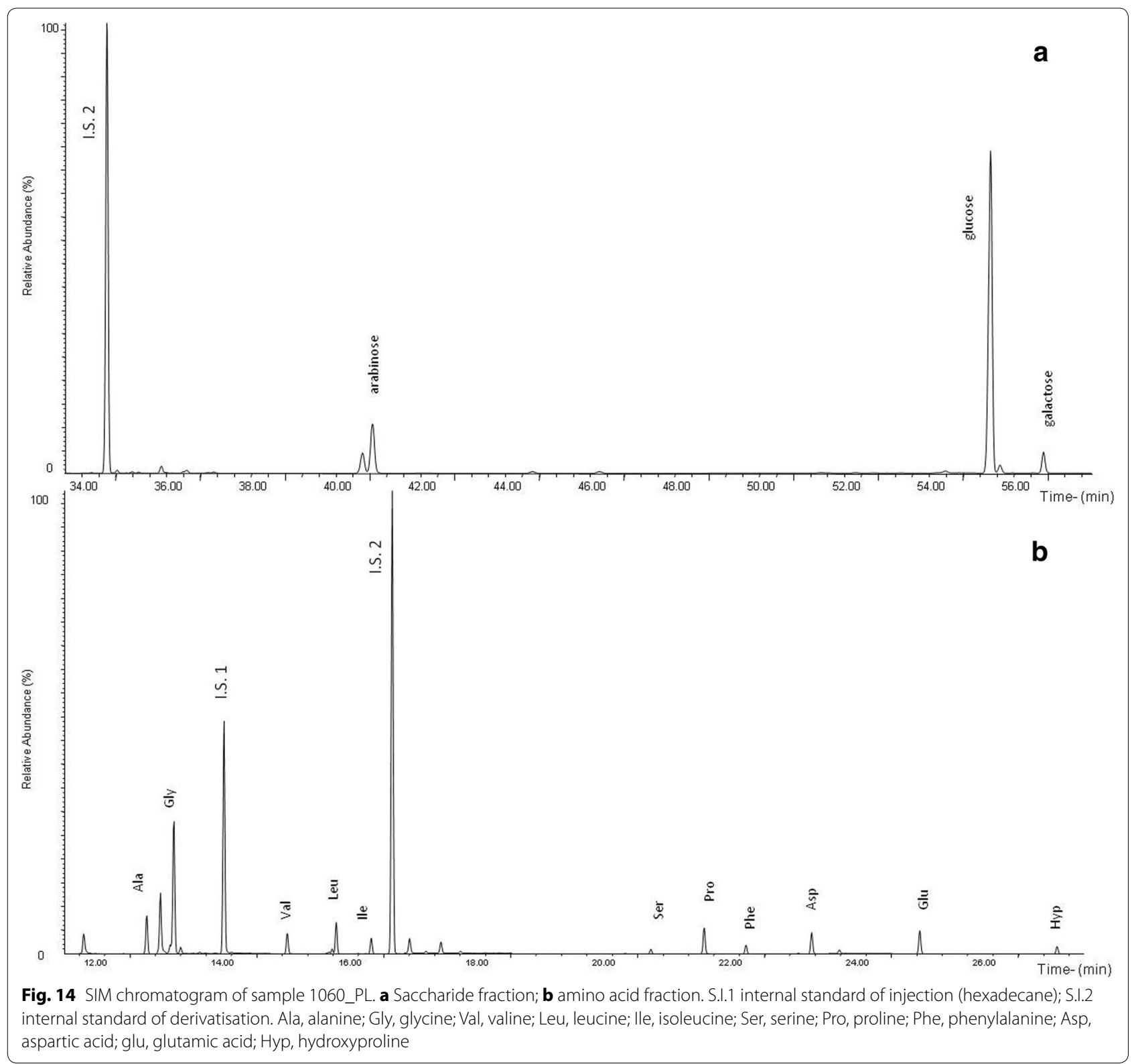

Table 1 Relative amino acid percentage content of sample 1060_-PL

\begin{tabular}{llllllllllll}
\hline Samples & ala & gly & val & leu & ile & ser & pro & phe & asp & glu & hyp \\
\hline $1060-\mathrm{PL}$ & 7.4 & 22.7 & 5.8 & 8.9 & 4.9 & 4.2 & 6.4 & 4.9 & 9.1 & 18.5 & 7.2 \\
\hline
\end{tabular}

Ala, alanine; Gly, glycine; Val, valine; Leu, leucine; Ile, isoleucine; Ser, serine; Pro, proline; Phe, phenylalanine; Asp, aspartic acid; glu, glutamic acid; Hyp, hydroxyproline

stronger response for egg white. This indicates that animal glue was used for the preparatory layer, while egg and plant gum were used as binders of the paint layer, which consisted of green earth [68]. Acacia gum mixed with a little protein material was also identified as paint binder in a cartonnage from a broad collar that has been radio-carbon dated to 512-351 $\mathrm{BCE}$ [11].

The absence of protein components in the samples from capital ÆIN 1045 and fragment ÆIN 1059 needs to be interpreted with caution because of the different 


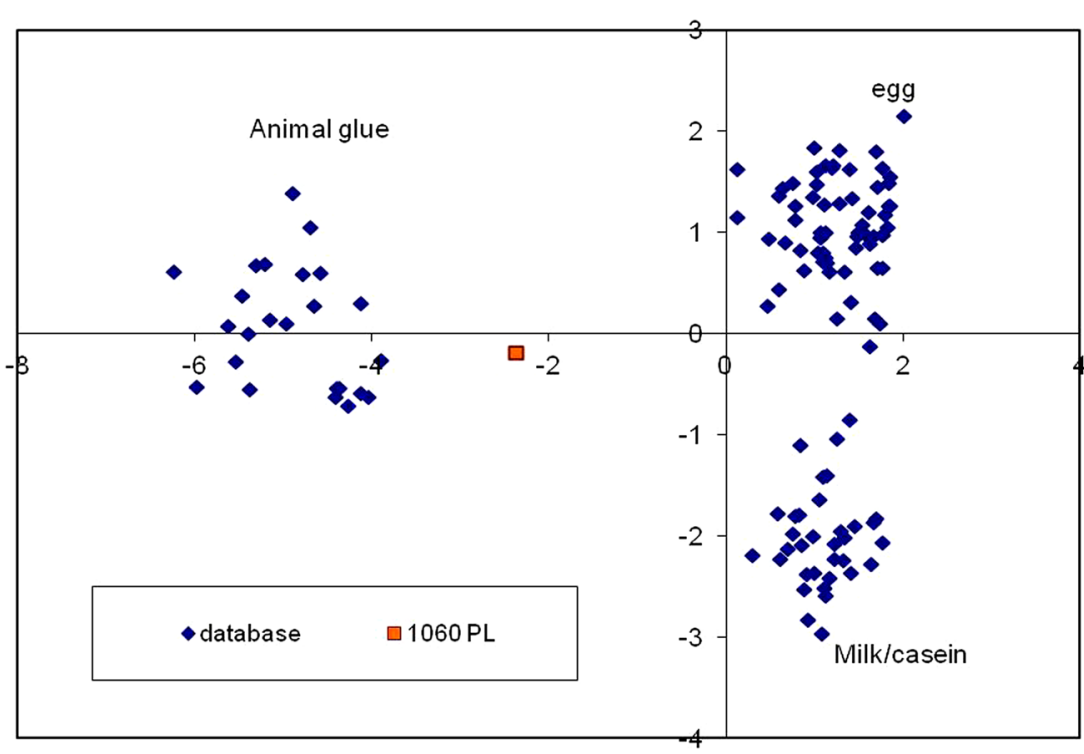

Fig. 15 Score plot (PC 1 on the abscissa and PC 2 on the ordinate) of sample ÆIN 1060_PL. The first two components accounted for the 89\% of the total variance of the data

Table 2 Summary of the results of FTIR and GC-MS analyses undertaken by the British Museum and the University of Pisa

\begin{tabular}{|c|c|c|c|}
\hline Sample ID & Description of the paint layer structure & FTIR results & GC-MS results \\
\hline EIN 1045_1 & $\begin{array}{l}\text { 1. Limestone support } \\
\text { 2. Beige ground layer } \\
\text { 3. Green paint layer } \\
\text { 4. Grey layer (not covering all the surface) }\end{array}$ & $\begin{array}{l}\text { 1. Not analyzed } \\
\text { 2. Possibly an organic binder } \\
\text { 3. Calcium oxalate, possibly an organic binder } \\
\text { 4. Calcium oxalate }\end{array}$ & $\begin{array}{l}\text { 1. Not analyzed } \\
\text { 2. Not analyzed } \\
\text { 3/4. Polysaccharide binder }\end{array}$ \\
\hline AIN 1045_2 & $\begin{array}{l}\text { 1. Limestone support } \\
\text { 2. Beige ground layer } \\
\text { 3. Green paint layer } \\
\text { 4. Translucent layer (not covering all the } \\
\text { surface) }\end{array}$ & $\begin{array}{l}\text { 1. Not analysed } \\
\text { 2. Possibly an organic binder } \\
\text { 3. Calcium oxalate, possibly an organic binder } \\
\text { 4. Wax }\end{array}$ & $\begin{array}{l}\text { 1. Not analysed } \\
\text { 2. Not analyzed } \\
\text { 3/4. Polysaccharide binder }\end{array}$ \\
\hline ÆIN 1048 & $\begin{array}{l}\text { 1. White ground layer } \\
\text { 2. Blue paint layer }\end{array}$ & No evidence of organic compounds & Not analysed \\
\hline EIN 1057 & $\begin{array}{l}\text { 1. Limestone support } \\
\text { 2. White layer } \\
\text { 3. Greenish-blue paint layer (blue and green } \\
\text { pigment dispersed in white matrix) } \\
\text { 4. Light yellow layer }\end{array}$ & $\begin{array}{l}\text { 1. No evidence of organic compounds } \\
\text { 2. Calcium oxalate } \\
\text { 3. Calcium oxalate } \\
\text { 4. Slight amounts of oxalate }\end{array}$ & Not analysed \\
\hline EIN 1059 & $\begin{array}{l}\text { 1. White layer } \\
\text { 2. Yellow paint }\end{array}$ & $\begin{array}{l}\text { 1. No evidence of organic compounds } \\
\text { 2. Calcium oxalate, possibly an organic binder }\end{array}$ & $\begin{array}{l}\text { 1. Not analyzed } \\
\text { 2. Polysaccharide binder }\end{array}$ \\
\hline EIN 1060 & $\begin{array}{l}\text { 1. White layer } \\
\text { 2. Yellow paint layer } \\
\text { 3. Whitish surficial layer }\end{array}$ & Not analyzed & $\begin{array}{l}\text { 1/2. Polysaccharide and proteinaceous } \\
\text { binders } \\
\text { 3. Beeswax }\end{array}$ \\
\hline
\end{tabular}

analytical methods used for analyses. It is not possible to say whether different areas were in fact painted with different mixtures of binders (plant gums in certain areas and plant gum in mixture with a protein material in others) or whether these differences are simply ascribable to the different detection limits of the analytical methods used. It should be also borne in mind that, for capital ÆIN 1045 and fragment ÆIN 1059, the uppermost set of layers (paint and coatings) were carefully separated from the ground layers prior to analysis. This might explain why no animal glue was identified in these samples. 


\section{Coatings}

Translucent waxy layers were seen on ÆIN 1045 (sample 2) and on ÆIN 1060 and identified as a synthetic wax (such as paraffin wax) and beeswax respectively.

Whilst the presence of a synthetic wax must be ascribed to the conservation of the fragments, the presence of beeswax is a somewhat complicated affair, as it is difficult to say whether this is a remnant of an original coating or a material added during conservation activities. It is known that beeswax was occasionally added to the artefacts after excavation as part of their conservation [46]. Petrie describes [69], p. 84 how he uses fresh beeswax to preserve the excavated mummy portraits from Fayum: "Many of the portraits were injured by damp but, by putting a coat of fresh beeswax on them, the old colour was revived and safely fixed, so that it would not drop away. In later years, paraffin wax was used for this purpose." In another instance, he writes that he secured the stucco on a lid by coating it with melted beeswax [69]. It appears that Petrie tended to use paraffin wax (invented in the 1850s) for this purpose rather than pure beeswax. He attests the use of paraffin wax on the Fayum mummy portraits in 1911: "There is no preservative so satisfactory as flooding over with melted paraffin wax; this must be hot enough to penetrate the cracks freely, but not so hot to melt the ancient wax paint." Petrie also used beeswax and paraffin wax to re-attach flaking gesso [70]. Several conservators have since used similar wax coatings for the conservation of wooden antiquities and mummy portraits, and the phenomenon is thus not exclusively related to Petrie. For example, A. Lucas recommends using paraffin wax for the consolidation of wooden antiquities [71, 72]. Paraffin wax was also used for Egyptian architecture: The Shrine of Taharqa (excavated in Nubia in 1931) in the Ashmolean was treated by conservators who removed as much of the previously applied cellulose nitrate as possible and replaced it with a thin coating of paraffin wax [73]. The paraffin wax was applied by either sprinkling, immersion or by brush in its molten state or as a solution in benzol wherever organic artefacts required consolidation. In fact, it became the standard field consolidation technique and remained so until the advent of synthetic polymers [74]. Since the use of beeswax as a consolidant is only attested for the mummy portraits, it appears likely that Petrie would rather have used paraffin wax for architectural elements such as the fragments from the Palace of Apries, however the use of beeswax obviously cannot be excluded, since he does not mention anything on the consolidants used on the finds from this particular site.

It is therefore possible that the beeswax attested on fragment ÆIN 1060 is of ancient origin.

In this case, it would be interesting to assess why the coating was found only in one of the investigated samples, covering a yellow area. Selective beeswax coatings have been found to cover areas painted with large-grained blue and green pigments in the Nebamun paintings [13], and on top of green paint in 18th-Dynasty relief fragments. Selective coatings were also found on top of red and yellow paints in the Tomb of Queen Nefertari [75] and in a number of Theban tomb-chapels [76]. It has been suggested that resin varnishing of some of these yellow paints may have been intended to create a glossy surface simulating gold [77]. It would be interesting to assess whether the coating found on fragment ÆIN 1060 was also applied on top of yellow areas in order to create a certain glossiness or highlight specific elements.

\section{Conclusions}

This study gives an account of the organic components (binders and coatings) found in the polychromy of the fragmental architectural reliefs from the Palace of Apries in Memphis, Egypt (26th Dynasty, ca. 589-568 BCE).

It is generally extremely difficult to detect and identify paint binders on architectural elements from archaeological contexts, since the organic components of the polychromy have usually deteriorated due to its exposure to the elements, in contrast to, e.g. material from tombs, which has been better protected from the environment.

The detection of polysaccharides in the paint layers on the capital (ÆIN 1045) and on two of the fragments (ÆIN 1059 and 1060) indicates the use of plant gums as binding media. The interpretation of the sugar profiles was not straightforward, so botanical classification was only possible for one of the fragments (ÆIN 1060), where the results of analysis seem to point to acacia gum. The sample from the same fragment was found to contain animal glue and a second protein material (possibly egg). While the presence of animal glue is probably ascribable to the binder used for the ground layer, the second protein indicates that either the paint layer was bound in a mixture of different binding materials or that the paint layer, bound in a plant gum, was then coated with a proteinaceous material.

Furthermore, calcium oxalate, a compound that is most likely ascribable to alteration processes of the original organic materials used to bind the layers, was detected in several of the investigated samples (capital ÆIN 1045, fragments ÆIN 1059 and 1057).

The absence of protein components in the other fragments needs to be interpreted with caution because of the different analytical method used for analysis. However, the possibility that different paint binders (plant gums in certain areas and plant gum in mixture with/ coated by a protein material in others) were specifically used in combination with specific pigments should be taken into consideration and needs to be explored further 
by focusing on pigment identification in combination with identification of binding media.

The surface of two of the fragments was partially covered with translucent waxy materials that were identified as a synthetic wax applied during old conservation treatments on ÆIN 1045 and as beeswax on ÆIN 1060. While we cannot exclude the use of beeswax as conservation material it is possible that the beeswax attested on fragment ÆIN 1060 is of ancient origin. In this case, wax might have been selectively applied on the yellow areas in order to create a certain glossiness or highlight specific elements.

\section{Authors' contributions \\ ALT, RS and MMDC: performed various parts of the chemistry. KLR and CB: drafted the manuscript. All authors read and approved the final manuscript.}

\section{Author details}

${ }^{1}$ Ny Carlsberg Glyptotek, Copenhagen, Denmark. ${ }^{2}$ CHART, Institute of Physics, Chemistry and Pharmacy, University of Southern Denmark, Odense, Denmark. ${ }^{3}$ Department of Scientific Research, The British Museum, London WC1B 3DG, UK. ${ }^{4}$ Dipartimento di Chimica e Chimica Industriale, Università di Pisa, Pisa, Italy.

\section{Acknowledgements}

We are very grateful to the Carlsberg Foundation for generously funding the research project Transmission and Transformation. Ancient Polychromy in an Architectural Context, whereof this study forms a part. We are also indebted to the Ny Carlsberg Glyptotek for housing the project and kindly granting permission to analyse the artefacts for this study. In this context we are grateful to Tine Bagh for assisting with the fragments and to Lin Spaabæk for sharing her expertise on ancient mummy portraits. We would also like to thank Maria Louise Sargent for all her work on the pigments of the fragments from the Palace of Apries and insightful comments and suggestions.

\section{Competing interests}

The authors declare that they have no competing interests.

\section{Availability of data and materials}

Further detailed data can be obtained from the authors upon request.

\section{Ethics approval and consent to participate}

Not applicable.

\section{Funding}

The project was supported by the Carlsberg Foundation via the project Transmission and Transformation. Ancient Polychromy in an Architectural Context.

\section{Publisher's Note}

Springer Nature remains neutral with regard to jurisdictional claims in published maps and institutional affiliations.

Received: 4 November 2017 Accepted: 1 February 2018 Published online: 20 February 2018

\section{References}

1. Orsini S, Parlanti F, Bonaduce I. Analytical pyrolysis of proteins in samples from artistic and archaeological objects. J Anal Appl Pyrol. 2017; 124:643-57.

2. Sotiropoulou S, Sciutto G, Lluveras Tenorio A, Mazurek J, Bonaduce I, Prati S, Mazzeo R, Schilling M, Colombini MP. Advanced analytical investigation on degradation markers in wall paintings. Microchem J. 2017 (Forthcoming).
3. Scott DA. A review of ancient pigments and cosmetics. Stud Conserv. 2016:61:185-202.

4. Chiavari G, Fabbri D, Galletti GC, Mazzeo R. Use of pyrolysis to characterize Egyptian painting layers. Chromatographia. 1995;40:594-600.

5. Lee L, Quirke S. Painting materials. In: Nicholson PT, Shaw I, editors. Ancient Egyptian materials and technology. Cambridge: Cambridge University Press; 2000. p. 104-20.

6. Lluveras-Tenorio A, Mazurek J, Restivo A, Colombini MP, Bonaduce I. Analysis of plant gums and saccharide materials in paint samples: comparison of GC-MS analytical procedures and databases. Chem Cent J. 2012;6:115.

7. Palet A, Porta E. Chemical analysis of pigments and media in the mural paintings of the tomb of Nefertari. In: VIII congress of conservation of cultural property. Valencia; 1990. p. 452-60.

8. Regert M, Colinart S, Degrand L. Chemical alteration and use of beeswax through time: accelerated aging tests and analysis of archaeological samples from various environmental contexts. Archaeometry. 2001;43:549-69.

9. Rowe S, Siddall R, Stacey R. A Roman Egyptian gilded cartonnage: technical study and conservation of a mummy mask from hawara. In: Dawson J, Rozeik C, Wright M, editors. Decorated surfaces on ancient Egyptian objects: technology, deterioration and conservation. London: Archetype Publications; 2010.

10. Sack SP, Tahk FC, Peters T. A technical examination of an ancient Egyptian painting on canvas. Stud Conserv. 1981;26:15-23.

11. Scott DA, Dodd LS, Furihata J, Tanimoto S, Keeney J, Schilling MR, Cowan E. An ancient Egyptian cartonnage broad collar: technical examination of pigments and binding media. Stud Conserv. 2004;49:177-92.

12. Scott DA, Warmlander S, Mazurek J, Quirke S. Examination of some pigments, grounds and media from Egyptian cartonnage fragments in the Petrie Museum, University College London. J Archaeol Sci. 2009:36:923-32.

13. Stacey R. Paint media and varnishes. In: Middleton A, Uprichard K, editors. The Nebamun wall paintings. Archetype Publications: London; 2008. p. $51-60$.

14. Newman R, Serpico M. Adhesives and binders. In: Nicholson PT, Shaw I, editors. Ancient Egyptian materials and technology. Cambridge: Cambridge University; 2000. p. 480.

15. Ambers J, Stacey R, Taylor J. Writing that cannot be erased: investigations of a box of pigmented inlays from the tomb chapel of an Old Kingdom noble. Br Mus Techn Res Bull. 2007;1:49-54.

16. Rowe S, Siddall R, Stacey R. Romano-Egyptian gilded cartonnage: technology and conservation of a gilded cartonnage mummy mask from Hawara. In: Decorated surfaces on ancient Egyptian objects: technology, deterioration and conservation. Proceedings of an icon archaeology group meeting at the Fitzwilliam Museum, University of Cambridge 7-9 September 2007. Archetype, London; 2010. p. 112.

17. Newman R, Serpico M. Adhesives and binders. In: Nicholson PT, Shaw I, editors. Ancient Egyptian materials and technology. Cambridge: Cambridge University Press; 2000. p. 476.

18. Ramer B. The technology, examination and conservation of the Fayum portraits in the Petrie Museum. Stud Conserv. 1979:24:6-7.

19. Scott DA, Warmlander S, Mazurek J, Quirke S. Examination of some pigments, grounds and media from Egyptian cartonnage fragments in the Petrie Museum, University College London. J Archaeol Sci. 2009;36(3):923-32

20. Newman R, Serpico M. Adhesives and binders. In: Nicholson PT, Shaw I, editors. Ancient Egyptian materials and technology. Cambridge: Cambridge University Press; 2000. p. 475.

21. LeFur D. La conservation des peintures murales des temples de Karnak. Paris; 1994. p. 59

22. Shedrinsky A, Wampler T, Indictor N, Baer NS. Application of analytical pyrolysis to problems in art and archaeology: a review. J Anal Appl Pyrol. 1989;15:402-3.

23. Newman R, Serpico M. Adhesives and binders. In: Nicholson PT, Shaw I, editors. Ancient Egyptian materials and technology. Cambridge: Cambridge University Press; 2000. p. 483.

24. Mazurek J, Svoboda M, Maish J, Kawahara K, Fukakusa S, Nakazawa T, Taniguchi Y. Characterization of binding media in Egyptian Roman portraits using enzyme-linked immunosorbent assay and mass spectrometry. e-Preserv Sci. 2014;11:76-83. 
25. Sack SP, Tahk FC, Peters T. A technical examination of an ancient Egyptian painting on canvas. Stud Conserv. 1981;26(1):15-23.

26. Salvant J, Williams J, Ganio M, Casaio F, Daher C, Sutherland K, Monico L, Vanmeert F, De Meyer S, Janssens K, Cartwright C, Walton M. A Roman Egyptian painting workshop: technical investigation of the portraits from Tebtunis, Egypt. Archaeometry; 2017. https://doi.org/10.1111/ arcm. 12351.

27. Newman R, Serpico M. Adhesives and binders. In: Nicholson PT, Shaw I, editors. Ancient Egyptian materials and technology. Cambridge: Cambridge University Press; 2000. p. 488.

28. Stulik S, Porta E, Palet A. Analyses of pigments, binding media, and varnishes. In: Corzo MA, Afshar MZ, editors. Art and eternity: the Nefertari wall paintings conservation project, 1986-1992. The Getty Conservation Institute: Marina del Rei; 1993. p. 63-5.

29. Wright MM, Wheals BB. Pyrolysis-mass spectrometry of natural gums, reins, and waxes and its use for detecting such materials in ancient Egyptian mummy cases (cartonnages). J Anal Appl Pyrol. 1987;11:195-211.

30. Granzotto C, Arslanoglu J. Revealing the binding medium of a Roman Egyptian painted mummy shroud. J Cult Heritage. 2017;27:170-4.

31. Serpico M, White R. Oil, fat and wax. In: Nicholson PT, Shaw I, editors. Ancient Egyptian materials and technology. Cambridge: Cambridge University Press; 2000. p. 409.

32. Masschelein-Kleiner L, Heylen J, Tricot-Marckx F. Contribution à l'analyse des liants, adhésifs et vernis anciens. Stud Conserv. 1968;13:107-10.

33. Langenheim JH. Plant resins: chemistry, evolution, ecology and ethnobotany.

Portland, Cambridge; 2003.

34. Vandenabeele P, Wehling B, Moens L, Edwards H, De Reu M, Van Hooydonk $G$. Analysis with micro-Raman spectroscopy of natural organic binding media and varnishes used in art. Anal Chim Acta. 2000;407:269.

35. Serpico M, White R. Resins, amber and bitumen. In: Nicholson PT, Shaw I, editors. Ancient Egyptian materials and technology. Cambridge: Cambridge University Press; 2000. p. 430-74.

36. Bonizzoni L, Bruni S, Guglielmi V, Milazzo M, Neri O. Field and laboratory multi-technique analysis of pigments and organic painting media from an Egyptian coffin (26th dynasty). Archaeometry. 2011;53(6):1227-9.

37. Alexopoulou-Agoranou A, Kalliga AE, Kanakari U, Pashalis V. Pigment analysis and documentation of two funerary portraits, which belong to the collection of the Benaki Museum. In: Bierbrier ML, editor. Portraits and masks: burial customs in Roman Egypt. British Museum Press: London; 1997:91, Fig. 19.5.

38. Spaabæk L. Conservation of mummy portraits at the Ny Carlsberg Glyptotek. In: Picton J, editors. Living images. Egyptian funerary portraits in the Petrie Museum. Walnut Creek; 2007. p. 123.

39. Newman R, Serpico M. Adhesives and binders. In: Nicholson PT, Shaw I, editors. Ancient Egyptian materials and technology. Cambridge: Cambridge University Press; 2000. p. 489.

40. Cuní J, Cuní P, Eisen B, Savizky R, Bove J. Characterization of the binding medium used in Roman encaustic paintings on wall and wood. Anal Methods. 2012;4:659-69.

41. Dietemann P, Stege H, Baumer U, Obermeier A, Steuer C, Sand L, Blänsdorf C, Fugmann E, Kaiser C. Pigmente und Bindemittel antiker Mumienporträts. In: Schmuhl Y, Wipfler EP, editors. Inkarnat und Signifikanz. Das menschliche Abbild in der Tafelmalerei von 200 bis 1250 im Mittelmeerraum. Munich; 2017. p. 201-19.

42. Catechini L, Mazurek J, Cantisani E, Lluveras-Tenorio A, Schilling M, Mussell C, Prati S, Sotiropoulou S, Rosi F, Miliani C, Sciutto G, Duce C, La Nasa J, Mazzeo R, Dyer J, Colombini MP. Ancient Encaustic: an experimental exploration of technology, ageing behaviour and approaches to analytical investigation. Microchem J. 2017 (Forthcoming).

43. Dietemann P, Stege H, Baumer U, Obermeier A, Steuer C, Sand L, Blänsdorf C, Fugmann E, Kaiser C. Pigmente und Bindemittel antiker Mumienporträts. In: Schmuhl Y, Wipfler EP, editors. Inkarnat und Signifikanz. Das menschliche Abbild in der Tafelmalerei von 200 bis 1250 im Mittelmeerraum. Munich; 2017. p. 215.

44. Translation: Morgan MH. Vitruvius. Cambridge: Harvard University Press. London: Humphrey Milford: 1914.

45. Mackay E. On the use of beeswax and resin as varnishes in Theban tombs. Ancient Egypt 5, 1920: 35-38; Newman R, Serpico M. Adhesives and binders. In: Nicholson PT, Shaw I, editors. Ancient Egyptian materials and technology. Cambridge: Cambridge University Press; 2000. p. 489.

46. Bonizzoni L, Bruni S, Guglielmi V, Milazzo M, Neri O. Field and laboratory multi-technique analysis of pigments and organic painting media from an Egyptian coffin (26th dynasty). Archaeometry. 2011;53(6):1212-30.

47. Reconstructions were carried out by Flinders Petrie: Petrie W.M.F. The Palace of Apries (Memphis II). London; 1909 and Kaiser: Kaiser W. Die dekorierte Torfassade des spätzeitlichen Palastbezirkes von Memphis. MDAIK. 1987:43:123-54.

48. Bagh T. Finds from W.M.F. Petrie's excavations in Egypt in the Ny Carlsberg Glyptotek. Copenhagen; 2011. p. 42.

49. Jørgensen M. Catalogue. Egypt IV. Late Egyptian sculpture 1080 BC-AD 400. Ny Carlsberg Glyptotek: Copenhagen; 2009.

50. Jørgensen M. Catalogue. Egypt IV. Late Egyptian sculpture 1080 BC-AD 400. Ny Carlsberg Glyptotek: Copenhagen; 2009. cat. 29.1.

51. Jørgensen M. Catalogue. Egypt IV. Late Egyptian sculpture 1080 BC-AD 400. Ny Carlsberg Glyptotek: Copenhagen; 2009. cat. 26.2.

52. Jørgensen M. Catalogue. Egypt IV. Late Egyptian sculpture 1080 BC-AD 400. Ny Carlsberg Glyptotek: Copenhagen; 2009. cat. 25.1.

53. Jørgensen M. Catalogue. Egypt IV. Late Egyptian sculpture 1080 BC-AD 400. Ny Carlsberg Glyptotek: Copenhagen; 2009. cat. 25.3.

54. Jørgensen M. Catalogue. Egypt IV. Late Egyptian sculpture 1080 BC-AD 400. Ny Carlsberg Glyptotek: Copenhagen; 2009. cat. 26.1.

55. The project is housed at the Ny Carlsberg Glyptotek in Copenhagen and financed by the Carlsberg Foundation: http://www.trackingcolour.com.

56. Lluveras A, Bonaduce I, Andreotti A, Colombini MP. GC/MS analytical procedure for the characterization of glycerolipids, natural waxes, terpenoid resins, proteinaceous and polysaccharide materials in the same paint microsample avoiding interferences from inorganic media. Anal Chem. 2010;82:376-86.

57. Examination by optical microscopy was carried out using a Leica MZ6 stereomicroscope and a ScopeTeck DCM900 digital camera to record images. Magnification calibration was confirmed with a microscope scale slide and appropriate scale bars were embedded into each image.

58. Bleton J, Mejanelle P, Sansoulet J, Goursaud S, Tchapla A. Characterisation of neutral sugars and uronic acids after methanolysis and trimethylsilylation for recognition of plant gums. J Chromatogr A. 1996;720:27-49.

59. Schilling MR. Paint media analysis-National Academy of Sciences. (Sackler NAS Colloquium) scientific examination of art: modern techniques in conservation and analysis. Washington, DC: The National Academies Press; 2005. https://doi.org/10.17226/11413.

60. Simek P, Heydová A, Jegorov A. High resolution capillary gas chromatography and gas chromatography-mass spectrometry of protein and non-protein amino acids, amino alcohols, and hydroxycarboxylic acids as their tert-butyldimethylsilyl derivatives. J High Resolut Chromatogr. 1994;17:145-52.

61. Sample fragments were initially examined by means of a low magnification stereo-microscope (Nikon SMZ 800 equipped with a Nikon Digital Camera UR-E6) and by an analytical microscope Eclipse LV 100 PDL (Nikon) equipped with a Digital Camera DMX 1200 F (Nikon).

62. Bonaduce I, Cito M, Colombini MP. The development of a gas chromatographic-mass spectrometric analytical procedure for the determination of lipids, proteins and resins in the same paint micro-sample avoiding interferences from inorganic media. J Chromatogr A. 2009;1216:5931-9.

63. Lluveras-Tenorio A, Mazurek J, Restivo A, Colombini MP, Bonaduce I. The development of a new analytical model for the identification of saccharide binders in paint samples. PLoS ONE. 2012;7(11):e49383. https://doi. org/10.1371/journal.pone.0049383.

64. Derrick MR, Stulik D, Landry JM. Infrared spectroscopy in conservation science. The Getty Conservation Institute: Los Angeles; 1999.

65. Bonaduce I, Colombini MP. Characterisation of beeswax in works of art by gas chromatography-mass spectrometry and pyrolysis-gas chromatography-mass spectrometry procedures. J Chromatogr A. 2004;1028:297-306.

66. Stacey R. Paint media and varnishes. In: Middleton A, Uprichard K, editors. The Nebamun wall paintings. Archetype Publications: London; 2008. p. 56.

67. Palet A, Porta E. Chemical analysis of pigments and media used in the mural paintings of the tomb of Nefertari. In: VIII congress of conservation of cultural property. Valencia; 1990. p. 452-60. 
68. Scott DA, Warmlander S, Mazurek J, Quirke S. Examination of some pigments, grounds and media from Egyptian cartonnage fragments in the Petrie Museum, University College London. J Archaeol Sci. 2009;36(3):930.

69. Petrie WMF. Seventy years in archaeology. London: Cambridge University Press; 1931

70. Petrie WMF. Hawara, Biahmu and Arsinoe. London: Field \& Tuer; 1899.

71. Lucas A. Antiques: their restoration and preservation. London; 1932

72. Spaabæk L. Conservation of mummy portraits at the Ny Carlsberg Glyptotek. In: J. Picton, editors. Living images. Egyptian funerary portraits in the Petrie Museum. Walnut Creek; 2007. p. 138, n.6.

73. Norman M. Early conservation techniques and the Ashmolean Museum. In: Watkins SC, Brown CE, editors. Conservation of ancient Egyptian materials. London; 1988. p. 11.
74. Norman M. Early conservation techniques and the Ashmolean Museum. In: Watkins SC, Brown CE, editors. Conservation of ancient Egyptian materials. London; 1988. p. 15.

75. Rickerby S. Original painting techniques and materials used in the tomb of Nefertari. In: Corzo MA, Afshar M, editors. Art and eternity. Santa Monica: Getty Conservation Institute; 1993. p. 48.

76. Mackay E. On the use of beeswax and resin as varnishes in Theban tombs. Ancient Egypt 5. 1920. p. 37.

77. Wilkinson CK, Hill M. Egyptian wall paintings: the Metropolitan Museum of Art's collection of facsimiles. New York: Metropolitan Museum of Art; 1983. p. 29.

\section{Submit your manuscript to a SpringerOpen ${ }^{\circ}$ journal and benefit from:}

- Convenient online submission

- Rigorous peer review

- Open access: articles freely available online

- High visibility within the field

- Retaining the copyright to your article

Submit your next manuscript at $\boldsymbol{\nabla}$ springeropen.com 